\title{
Magmatic differentiation in the calc-alkaline Khalkhab-Neshveh pluton, Central Iran
}

\author{
Mehdi Rezaei-Kahkhaei ${ }^{\mathrm{a}, *}$, Carmen Galindo ${ }^{\mathrm{b}}$, Robert J. Pankhurst ${ }^{\mathrm{c}}$, Dariush Esmaeily ${ }^{\mathrm{a}}$ \\ ${ }^{a}$ School of Geology, College of Science, University of Tehran, PO 14155-6455, Iran \\ ${ }^{b}$ Departmento de Petrología y Geoquímica, Universidad Complutense-IGEO (UCM-CSIC), C/José Antonio Novais $n^{\bullet} 2,28 \bullet 40$ Madrid, Spain \\ ${ }^{c}$ Visiting Research Associate, British Geological Survey, Nottingham, United Kingdom
}

Keywords:

Crystal fracionation

Isotope geochemistry

Quartz monzogabbro

Granite

Urumieh-Dokhtar magmatic arc

\begin{abstract}
A B S T R A C T
Geochemical and isotopic data ( $\mathrm{Sr}, \mathrm{Nd}$ ) are presented for the Khalkhab-Neshveh pluton, an E-W elongated body of quartz monzogabbro, quartz monzodiorite, granodiorite and granite in the UrumiehDokhtar magmatic arc of Central Iran. The plutonic rocks are medium- to high- $\mathrm{K}$, metaluminous, and I-type, with $52-71$ wt.\% $\mathrm{SiO}_{2}$. The geochemistry shows smooth differentiation trends in which most major elements (except $\mathrm{Al}_{2} \mathrm{O}_{3}, \mathrm{~K}_{2} \mathrm{O}$ and $\mathrm{Na}_{2} \mathrm{O}$ ) are negatively correlated with $\mathrm{SiO}_{2} ; \mathrm{K}_{2} \mathrm{O}, \mathrm{Ba}, \mathrm{Rb}, \mathrm{Ce}, \mathrm{Nb}$, and $\mathrm{Zr}$ are positively correlated. $\mathrm{Na}_{2} \mathrm{O}, \mathrm{Sr}, \mathrm{Eu}$ and $\mathrm{Y}$ follow curves that are not considered to represent simple mixing between mafic and felsic magmas, but reflect crystal fractionation of clinopyroxene, plagioclase and hornblende. Initial ${ }^{87} \mathrm{Sr} /{ }^{86} \mathrm{Sr}$ ratios $(\sim 0.7047)$ and $\varepsilon N d t$ values $(\sim+3.0)$ are essentially constant, and the large volume of quartz monzogabbros compared to granites, as well as the lack of mafic enclaves in more evolved rocks, are also indicative of crystal fractionation rather than mixing of magmas from different sources. Clinopyroxene fractionation was the main control in the evolution of the magmas up to $55 \% \mathrm{SiO}_{2}$; hornblende took over from $55 \mathrm{wt} . \%$, resulting in decreasing Dy/Yb with increasing silica content in the most siliceous rocks. Sr concentration increases up to $55 \% \mathrm{SiO}_{2}$, and then decreases together with $\mathrm{CaO}, \mathrm{Al}_{2} \mathrm{O}_{3}, \mathrm{Na}_{2} \mathrm{O}$. Fractionation of opaque minerals and apatite throughout the sequence, and the continuous increase in $\mathrm{K}_{2} \mathrm{O}$ and $\mathrm{Ba}$ vs. $\mathrm{SiO}_{2}$ reflect the absence of significant fractionation of biotite and K-feldspar. Based on geochemical and isotope data, geophysics information and field studies, it seems that suturing of the Arabia and Iran plates caused the Khalkhab and Koush nousrat faults with leftlateral strike-slip in the Urumieh-Dokhtar region, and generated a purely tensional T space at $32^{\bullet}$ to the faults which was exploited by the emplacement of Khalkhab-Neshveh pluton.
\end{abstract}

\section{Introduction}

Volcanic arc igneous rocks in orogenic belts mostly range in composition from gabbro-diorite to granite (Eichelberger, 1980; Hildreth, 1981; Furlong and Fountain, 1986; Arndt and Goldstein, 1989; Bergantz, 1989). This wide variation is variously ascribed to crystal fractionation, multi-pulse intrusion when the new pulse has different composition compare to the previous magma, magma mixing, variable degrees of restite separation, and contamination by assimilation (Chappell et al., 1987; Roberts and Clemens, 1995). Crystals and melts may separate in a closed system from a parental magma in various ways: by the separation of entrained restite, gravitational crystal settling or wall-rock accumulation (especially in basaltic magmas), or by mechanisms such as

\footnotetext{
* Corresponding author. Tel.: +98 9153491004; fax: +98 2166491623.

E-mail addresses: Mehdi.Rezaei@khayam.ut.ac.ir (M. Rezaei-Kahkhaei), cgalindo @geo.ucm.es (C. Galindo), rjpt@bgs.ac.uk (R.J. Pankhurst), Esmaili@Khayam.ut.ac.ir (D. Esmaeily).
}

filter-pressing processes or in situ crystallization in the intermediate and acidic magmas (Tindle and Pearce, 1981; Walker and Carr, 1986; Blevin and Chappell, 1992; Dias and Leterrier, 1994; Claeson and Meurer, 2004). The system becomes open when the parental magma is contaminated in some ways, either by assimilation of wall rock during ascent or emplacement, or by the mingling and ultimately mixing with a different magma. The only way of confidently distinguishing open and closed systems is by means of isotopic ratios (e.g. ${ }^{87} \mathrm{Sr} /{ }^{86} \mathrm{Sr}$ and ${ }^{143} \mathrm{Nd} /{ }^{144} \mathrm{Nd}$ ). While in a closed system there is little change in these isotope ratios, interaction of two magmas from different sources or magma with wall rocks will generally result in a significant change in these parameters (Galán et al., 1996; Wei et al., 1997; Verma, 2001; Lassen et al., 2004).

The types of change that are typically seen during magmatic differentiation (Sha and Chappell, 1999; Broska et al., 2004) include: (a) major elements such as $\mathrm{SiO}_{2}$ and $\mathrm{K}_{2} \mathrm{O}$ increase in abundance, but others such as $\mathrm{TiO}_{2}, \mathrm{Fe}_{2} \mathrm{O}_{3}, \mathrm{MgO}$ and $\mathrm{CaO}$ decrease, (b) $\mathrm{Mg} / \mathrm{Fe}$ and $\mathrm{Ca} / \mathrm{Na}$ ratios decrease, (c) concentrations of trace elements such as $\mathrm{Rb}, \mathrm{Sn}, \mathrm{Cs}, \mathrm{W}$ and $\mathrm{U}$ rise, (d) those elements such as $\mathrm{V}, \mathrm{Cr}$, 


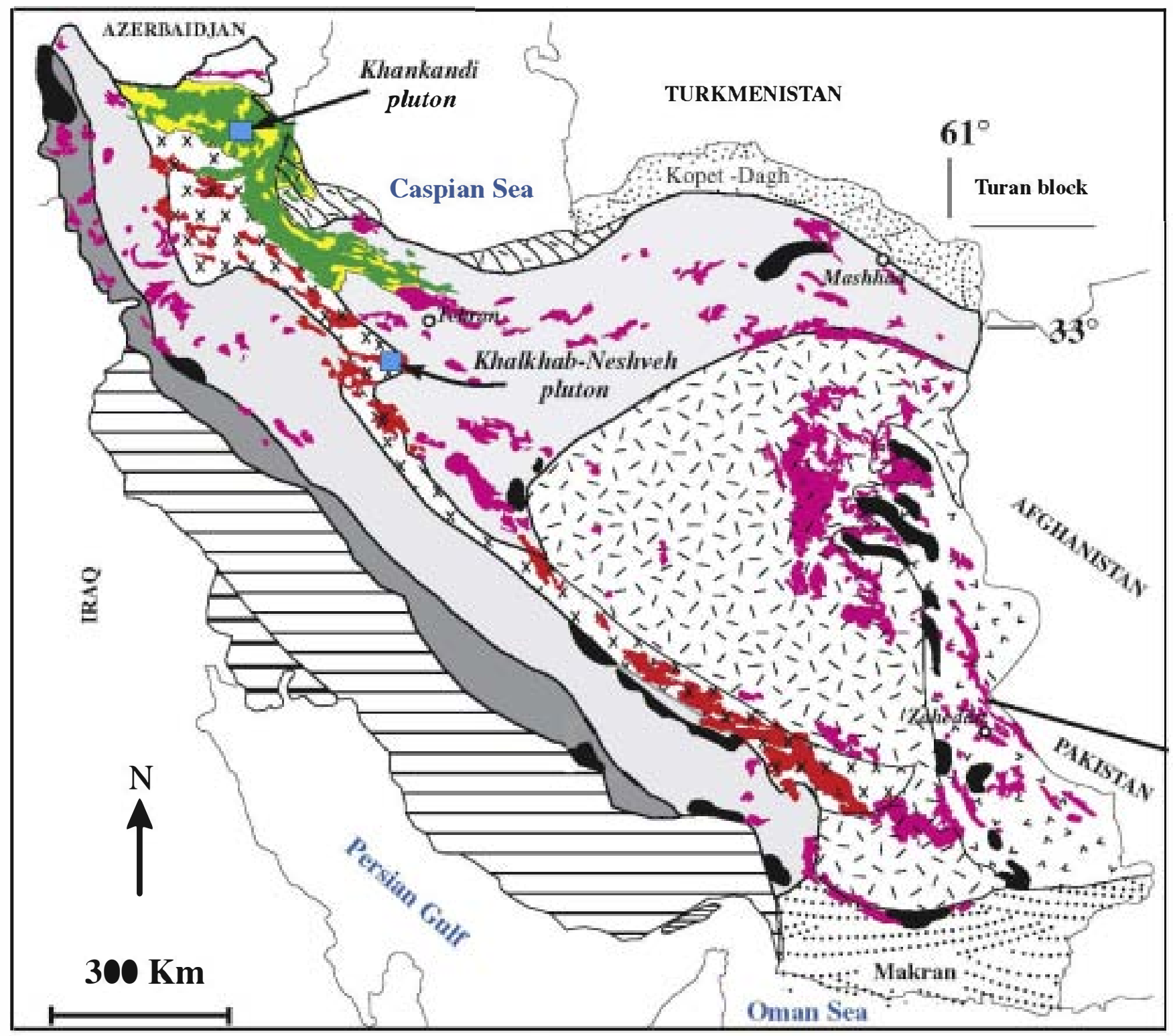

\begin{tabular}{|c|c|c|c|c|}
\hline - & Dezful embayment & Sanandaj-Sirjan zone & & Peri-Caspian basin \\
\hline & Folded Zagros & Central Iran & $<><$ & Sistan suture zone \\
\hline & Ophiolites & $\begin{array}{l}\text { Western Alborz } \\
\text { Magmatic Belt }\end{array}$ & : & Makran \\
\hline$x \times x \times$ & $\begin{array}{l}\text { Drumich-Dokhtar } \\
\text { Magmatic Aro }\end{array}$ & $\begin{array}{l}\text { Plutonic rocks of Western } \\
\text { Alborz magmatic belt }\end{array}$ & $-1=1-1$ & Lut Block \\
\hline & $\begin{array}{l}\text { Plutonic rocks of Urumieh- } \\
\text { Dokhtar magmatic arc }\end{array}$ & Kopet -Dagh & & Other putonic rocks \\
\hline
\end{tabular}

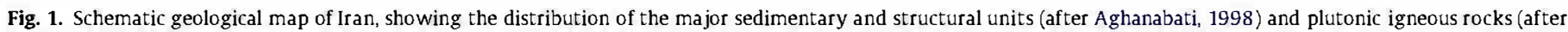
Aghanabati, 1991). The Urumieh-Dokhtar and Alborz magmatic arcs are both of mostly Eocene-Miocene age, some of the other igneous rocks are older.

$\mathrm{Ni}, \mathrm{Zn}$ and Sr fall, (e) some trace elements may rise or fall depending on whether or not the melt is saturated in the dominant mineral containing that element, e.g. $\mathrm{Zr}$ and $\mathbf{B a}$, (f) in some cases mineral saturation in felsic melts depends on whether the melt is I- or S-type, the most important example being apatite saturation which is a feature of felsic I-type melts ( $P$ falls) but not of more strongly peraluminous $\mathrm{S}$-type melts ( $\mathrm{P}$ rises).
The Urumieh-Dokhtar magmatic arc is a volcanic-plutonic belt that crosses Central Iran in a NW-SE direction (Fig. 1). The arc outcrops mainly consist of Eocene-Miocene volcano-sedimentary sequences and associated plutonic rocks typical of calcalkaline magmatism developed at active continental margins. The arc developed during the closure of the Neotethyan Ocean between Arabia and Eurasia (e.g., Dercourt et al., 1986; Ricou 


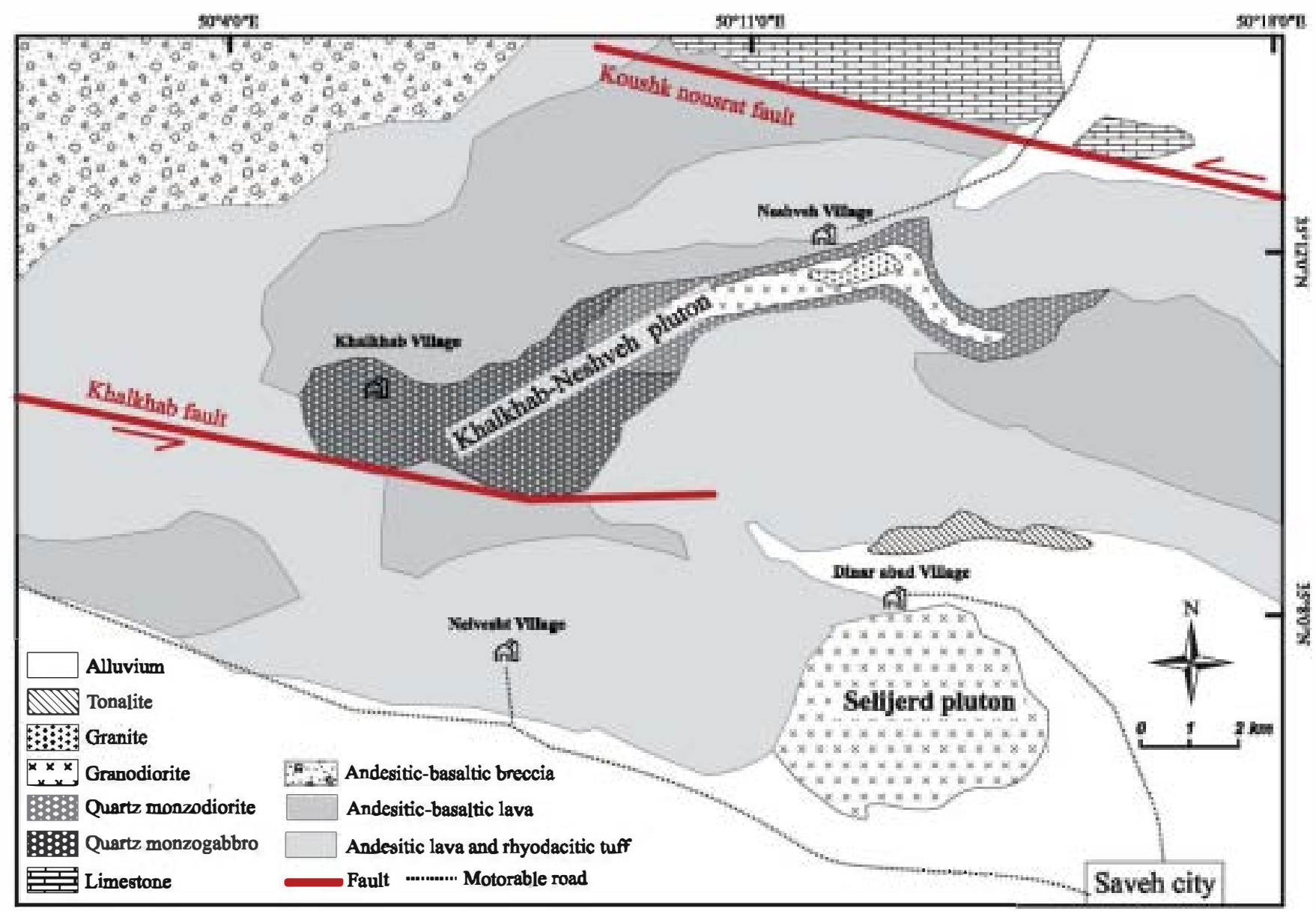

Fig. 2. Simplified geological map of NW Saveh intrusions (Based on satellite data and the geological map of Saveh 1:100,000; Ghalamghash, 1998).

et al., 1977; Agard et al., 2007), and has been the subject of geophysical, kinematic, and neotectonic studies (McQuarrie et al., 2003; Talebian and Jackson, 2004; Vernant et al., 2004; Molinaro et al., 2004, 2005; Meyer et al., 2005). Little is known, however, about the magmatic activity of the Urumieh-Dokhtar magmatic arc, which was active from Tertiary to Pliocene-Quaternary times (Fig. 1; Hassanzadeh, 1993; McQuarrie et al., 2003; Torabi, 2009).

Intrusive rocks in the Urumieh-Dokhtar magmatic arc show a large range of rock types, dominated by granite, but with small amounts of granodiorite, quartz diorite and gabbro. The plutonic rocks are widely distributed, covering more than $65 \%$ of the outcrop area. Previous petrological studies have concentrated mainly on the tectonic setting of the intermediate-acidic volcanic-plutonic rocks (see references above). The Khalkhab-Neshveh pluton is located $12 \mathrm{~km} \mathrm{NW}$ of the city of Saveh (Figs. 1 and 2). It contains quartz monzogabbro, quartz monzodiorite, granodiorite and granite. In this paper, we combine field and petrography studies with whole-rock geochemical and isotope data to test whether these various rocks were generated by crystal fractionation or by mixing between basaltic and felsic magmas. Finally, we offer a tectonomagmatic model for this pluton.

\section{Geological setting}

The country rocks of the pluton are dominated by andesitic lava and rhyodacitic tuff, andesitic-basaltic lava and andesitic-basaltic breccia associated with limestones (Fig. 2; Ghalamghash, 1998; Davarpanah, 2009).
Andesitic lava and rhyodacitic tuff are the oldest rocks; they are exposed in the central part of the map area and have the longest contact with the plutonic rocks (Fig. 2). In places they include hyaloclastic lava with interlayers of andesitic and basaltic composition. The green ${ }^{1}$ rhyodacitic tuff is dominantly composed of volcanic grains which, due to explosive acidic eruptions, were ejected as glass shards (now devitrified) and other fragments into a marine environment, forming green minerals such as chlorite and epidote, with various clay minerals (Winter, 2001; Davarpanah, 2009).

The andesitic-basaltic lavas are dark green and brown in colour, with medium-grained phenocrysts, and have minor beds of andesitic tuff. Plagioclase occurs as phenocrysts that range in size from less than $0.2 \mathrm{~mm}$ to several $\mathrm{mm}$. In addition to the ubiquitous laths of plagioclase, the basaltic lavas contain olivine and pyroxene, in places altered to iddingsite, and actinolite and chlorite, respectively. The lavas occur as clumps a few $\mathrm{mm}$ to $\mathrm{cm}$ in size within a highly hydrated, oxidised, and altered volcanic matrix, suggesting eruption in a shallow marine environment. In many cases, the exterior margin of these blobs consists of volcanic glass or oxidised material, while the interior parts are more intact, and have preserved an original volcanic texture and structure (Davarpanah, 2009).

The andesitic-basaltic breccia is exposed in the northwest of the map area (Fig. 2). A sequence of hyaloclastic breccia and tuff at the base grade upwards into aphyric lava followed by autoclastic breccia at the top. The tuff grains vary in size from a few mm to a few

\footnotetext{
${ }^{1}$ For interpretation of colour in Figs. 1-4, 8 and 15, the reader is referred to the web version of this article.
} 


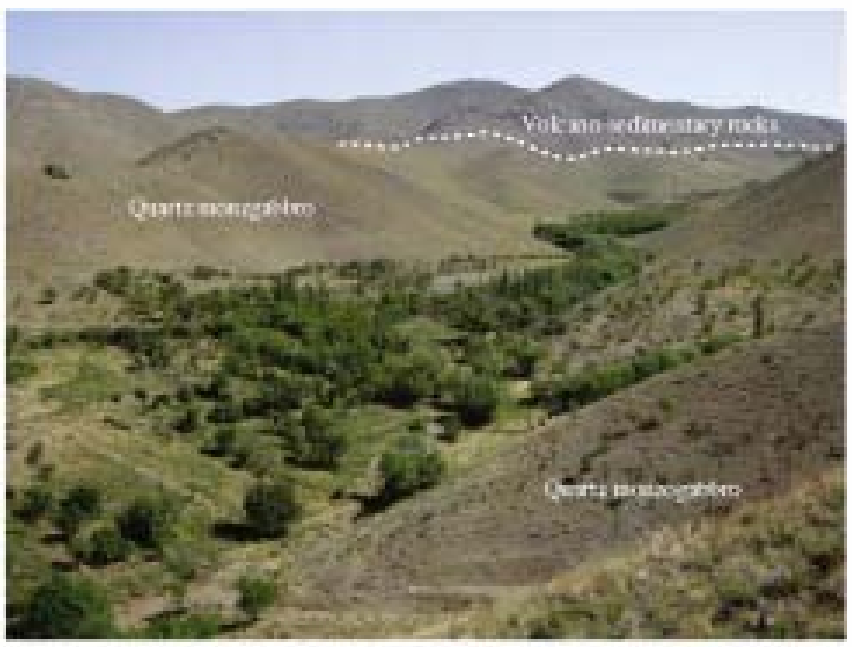

Fig. 3. Field photograph showing quartz monzogabbros of the Khalkhab-Neshveh pluton intruded into the volcano-sedimentary rocks.

$\mathrm{cm}$, and the smaller grains are replaced by green minerals such as chlorite and epidote, probably because of reaction with water, whereas the larger grains are less altered. Hand specimens show altered phenocrysts of clinopyroxene and plagioclase. Moreover, the olivine basaltic lava at the middle of the sequence and the hyaloclastic breccia at the top might indicate explosive volcanic/volcaniclastic activity under water, probably in a marine basin (Davarpanah, 2009).

The chemical compositions of the volcanic rocks show a calcalkaline affinity, enrichment in LIL elements ( $R b, B a, T h, U$, and $\mathrm{Pb}$ ) and depletion in $\mathrm{Nb}, \mathrm{Ti}$, and $\mathrm{Zr}$ (Davarpanah, 2009). Significant $\mathrm{U}$ enrichment relative to $\mathrm{Nb}$ and $\mathrm{Th}$ is mainly a result of source enrichment by slab-derived fluids. The results of geochemical modelling suggest a mantle lithosphere source for these volcanic rocks (Winter, 2001; Davarpanah, 2009).

Two plutonic bodies, Khalkhab-Neshveh and Selijerd, were intruded into the volcano-sedimentary rocks (Figs. 2 and 3). The former comprises quartz monzogabbro, quartz monzodiorite, granodiorite and granite, while the Selijerd pluton in the southern map area consists of tonalitic and granodioritic rocks. Ghasemi et al. (2008) reported three Rb-Sr isotope analyses for Seli jerd plutonic samples (two diorite and a granite). Unpublished U-Pb zircon dating by Rezaei-Kahkhaei and Corfu (in progress) confirms an Eocene age all lithological groups in the Khalkhalb-Neshveh pluton.

\section{Petrography and field relationship}

The Khalkhab-Neshveh pluton covers an area of about $22 \mathrm{~km}^{2}$ and consists of a wide spectrum of rock types, which form highelevation terrains. It was subdivided into two compositional zones: quartz monzogabbro in the West and quartz monzodiorite, granodiorite and granite in the East (Fig. 2 and Table 1) based on mineralogy and using the terminology of Middlemost (1985). The contacts are gradational but the rock types are distinct and easily recognized both in outcrop and in aerial photographs.

\subsection{Quartz monzogabbro}

The quartz monzogabbro is poorly exposed in the western part of map area and was intruded into the volcanic rocks (Fig. 3). It occupies about $50 \%$ of the pluton and is medium- to coarse-grained with various textures; some samples show intergranular and poikilitic textures, while others show granular texture (Fig. 4A). The intergranular texture is constituted by grains of clinopyroxene which occupy the angular interstices between plagioclase crystals. The quartz monzogabbro consists dominantly of plagioclase (51.555.6 modal\%), clinopyroxene (20.2-25.7\%), K-feldspar (9-14.1\%), quartz $(7.9-11.7 \%)$, and subordinate opaque minerals $(2.3-3.5 \%)$ and apatite $(<0.6 \%)$ (Table 1 ).

Clinopyroxene is a primary mafic phase in the rock and amphibole is absent as a primary phase. In a few samples, especially of the porphyritic quartz monzogabbro, clinopyroxene is replaced completely by actinolite. Plagioclase forms mainly euhedral and lath-shaped crystals. Large plagioclase crystals ( $>3 \mathrm{~mm}$ ) often contain many inclusions of clinopyroxene and opaque minerals (Fig. 4A). They mainly show zoning, twinning and prismatic-cellular growth. Some large crystals of plagioclase are altered to sericite and clay minerals. Quartz and $\mathbf{K}$-feldspar are anhedral and occupy the interstices between plagioclase tablets, suggesting late crystallization. They occasionally show a graphic intergrowth.

\subsection{Quartz monzodiorite}

The quartz monzodiorite surrounds the granodiorite and granite. To the west, quartz monzodiorite is transitional to more mafic rocks, the quartz monzogabbro while to the east it forms the margin of the pluton (Fig. 2). The quartz monzodiorite is generally medium-grained and characterized by equigranular texture. It consists dominantly of plagioclase (41.1-52.4 modal\%), K-feldspar (9-19\%), quartz (10.9-18.4\%), hornblende (6.9-16.3\%) and subordinate clinopyroxene $(0-12.1 \%)$, biotite $(2.5-5 \%)$ and opaque minerals $(2.3-3 \%$ ) (Table 1$)$. Accessory minerals such as titanite and apatite are rare. Clinopyroxene is subhedral and, in some samples, replaced by hornblende, actinolite and biotite aggregates. Hornblende is common in the quartz monzodiorite, where it occurs as euhedral to subhedral and isolated crystals, sometimes accompanied by biotite (Fig. 4B). Minor interstitial quartz occurs in crude graphic intergrowth with $\mathbf{K}$-feldspar. Opaque minerals are rare but typically form euhedral grains.

Table 1

Modal mineralogical compositions of Khalkhab-Neshveh igneous rocks.

\begin{tabular}{|c|c|c|c|c|c|c|c|c|c|c|c|c|c|c|c|}
\hline \multirow[b]{2}{*}{ Sample no. } & \multicolumn{5}{|c|}{ Quartz monzogabbro } & \multicolumn{5}{|c|}{ Quartz monzodiorite } & \multicolumn{3}{|c|}{ Granodiorite } & \multicolumn{2}{|c|}{ Granite } \\
\hline & SK11 & SK 42 & SK18 & SK5 & SK64 & SK58 & SK62 & SN10 & SN11 & SK66 & SN17 & SN15 & $\mathrm{SN} 44$ & SN52 & SK56 \\
\hline $\mathrm{SiO}_{2}(w t . \%)$ & 52.1 & 52.2 & 53.2 & 54.7 & 55.5 & 55.1 & 56.7 & 56.5 & 59.6 & 60.8 & 62.5 & 62.7 & 65.1 & 69.4 & 71.2 \\
\hline Quartz & 8.6 & 7.9 & 9.1 & 10.7 & 11.7 & 11.1 & 12.0 & 10.9 & 17.2 & 18.4 & 19.5 & 20.3 & 21.3 & 30.0 & 33.0 \\
\hline K-feldspar & 12.0 & 10.3 & 10.2 & 14.1 & 9.0 & 11.0 & 9.0 & 9.8 & 16.6 & 19.0 & 16.9 & 15.0 & 25.0 & 29.7 & 28.0 \\
\hline Plagioclase & 52.6 & 53.0 & 53.2 & 51.5 & 55.6 & 51.5 & 50.5 & 52.4 & 43.2 & 41.1 & 44.7 & 44.4 & 41.1 & 35.0 & 32.0 \\
\hline Clinopyroxene & 24.6 & 25.7 & 23.9 & 20.8 & 20.2 & 12.1 & 9.5 & 4.5 & 2.7 & 0.0 & 1.2 & 0.4 & 0.0 & 0.0 & 0.0 \\
\hline Hornblende & 0.0 & 0.0 & 0.0 & 0.0 & 0.0 & 6.9 & 13.0 & 14.1 & 13.0 & 16.3 & 11.0 & 12.3 & 11.2 & 2.3 & 4.0 \\
\hline Bionte & 0.0 & 0.0 & 0.0 & 0.0 & 0.0 & 4.1 & 2.5 & 5.0 & 4.5 & 3.0 & 3.6 & 5.4 & 0.0 & 2.2 & 1.2 \\
\hline Apatite & 0.0 & 0.4 & 0.1 & 0.0 & 0.6 & 0.7 & 0.6 & 0.7 & 0.1 & 0.1 & 0.2 & 0.1 & 0.0 & 0.0 & 0.0 \\
\hline Opaque & 2.3 & 2.6 & 3.5 & 2.9 & 2.9 & 2.5 & 3.0 & 2.8 & 2.6 & 2.3 & 2.9 & 2.0 & 1.2 & 0.8 & 0.8 \\
\hline Counted points & 1103 & 1503 & 1938 & 1384 & 1235 & 1698 & 1428 & 1367 & 1251 & 2387 & 1137 & 1600 & 1376 & 1345 & 1212 \\
\hline
\end{tabular}



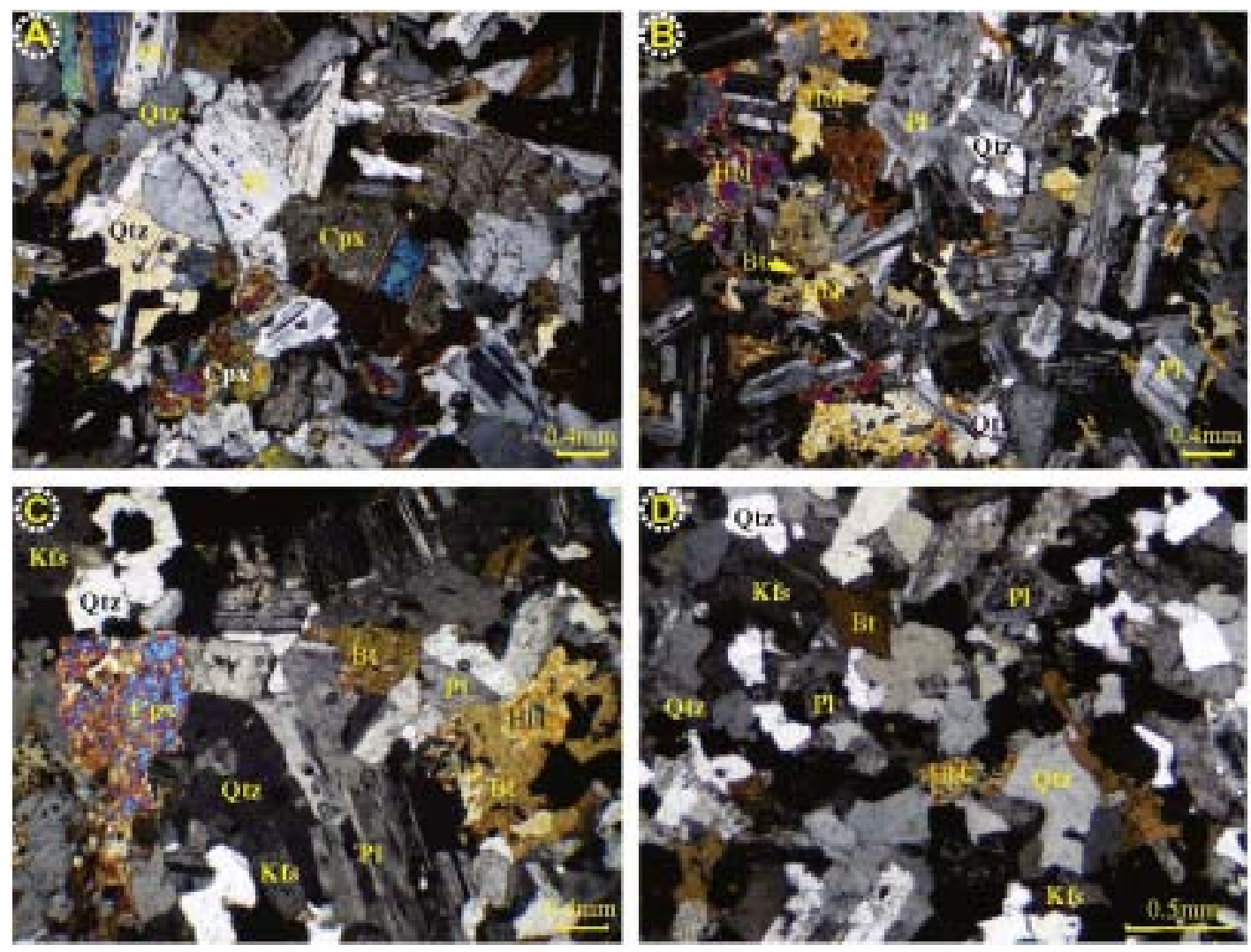

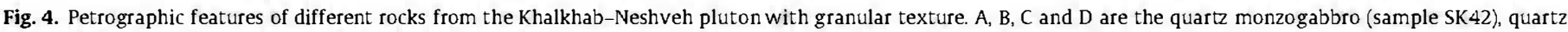
monzodiorite (sample SN10), granodiorite (sample SN17) and granite (sample SN52), respectively. Abbreviations are after Kretz (1983).

\subsection{Granodiorite}

About $20 \%$ of the pluton is constituted by granodiorite, emplaced within the quartz monzodiorite hosted by volcanic rocks and limestone. It is relatively homogeneous, white to pale grey massive rocks with a medium-grained texture. The mineral assemblages consist of plagioclase (41.1-44.7 modal\%), K-feldspar $(15-25 \%)$, quartz $(19.5-21.3 \%)$, hornblende $(11-12.3 \%)$, biotite $(0-5.4 \%)$, opaque minerals $(1.2-2.9 \%)$ and clinopyroxene $(<1.2 \%)$ with traces of accessory minerals. Mafic phases are well-formed hornblende and biotite. Biotite forms individual crystals in the granodiorite and is sometimes observed in contact with euhedral to subhedral hornblende crystals (Fig. 4C). Plagioclase occurs as zoned subhedral crystals, $0.3-1 \mathrm{~mm}$ in diameter and usually twinned. Subhedral to anhedral K-feldspar crystals have locally microperthitic texture.

\subsection{Granite}

The white granites are restricted to the centre of pluton (Fig. 2). They are generally medium-grained and have granular to porphyritic textures with megacrysts of plagioclase. They contain plagioclase (32-35 modal\%), K-feldspar (28-29.7\%) and quartz (30-33\%) with mafic minerals of green hornblende (2.3$4 \%$ ) and biotite (1.2-2.2\%) (Fig. 4D). There are two kinds of plagioclase in the granitic rocks including medium-grained and large phenocrysts $(\sim 2 \mathrm{~mm})$. Some of $\mathbf{K}$-feldspars are altered, particularly to clay minerals, and occasionally show intergrowth with quartz. Otherwise, quartz is medium-grained and shows undulose extinction. Green hornblende is partially replaced by chlorite and opaque minerals. Magnetite and hematite are the main opaque minerals.

\section{Analytical methods}

Fifteen fresh whole-rock samples representative of the petrological range at Khalkhab-Neshveh were analysed for major and trace elements by ICP after fusion of $0.2 \mathrm{~g}$ rock powder with $1.5 \mathrm{~g}$ $\mathrm{LiBO}_{2}$, and dissolution in $100 \mathrm{ml} \mathrm{5 \%} \mathrm{HNO}_{3}$. Loss on ignition (LOI) was determined by drying the samples at $1000^{\circ} \mathrm{C}$. Rare earth element analyses were performed by ICP-MS at ALS Chemex Company in Canada. Detection limits range 0.01-0.1 wt.\% for major oxides, 0.1-10 ppm for trace elements, and 0.01-0.5 ppm for the rare earth elements. Full ma jor and trace element compositions are given in Table 2.

$\mathrm{Sr}$ and $\mathrm{Nd}$ isotope analyses were carried out at Universidad Complutense, Madrid, using standard separation and mass-spectrometric techniques. The decay constants used in the calculations are: $\lambda^{87} \mathrm{Rb}=1.42 \times 10^{-11}$ and $\lambda^{147} \mathrm{Sm}=6.54 \times 10^{-12}$ year $^{-1}$ recommended by the IUGS Subcommision for Geochronology (Steiger and Jäger, 1977). Results are reported in Table 3, together with the Sr isotope data of Ghasemi et al. (2008) for the Selijerd pluton.

\section{Geochemistry}

The calc-alkaline chemistry of the rocks is illustrated in Fig. 5, after Rickwood (1989): the samples all plot in the calc-alkaline field. The molecular ratio of $\mathrm{Al}_{2} \mathrm{O}_{3} /\left(\mathrm{CaO}+\mathrm{Na}_{2} \mathrm{O}+\mathrm{K}_{2} \mathrm{O}\right)$ ranges from 0.73 to 1 , exhibiting metaluminous characteristics (not shown here). Features such as $\mathrm{Na}_{2} \mathrm{O}>\mathrm{K}_{2} \mathrm{O}$ and $\mathrm{A} / \mathrm{CNK}<1$ are characteristic of I-type rocks (White and Chappell, 1983), which is also consistent with the presence of key modal minerals such as hornblende and titanite. The rocks are sodic as shown by the high average values of $\mathrm{Na}_{2} \mathrm{O} / \mathrm{K}_{2} \mathrm{O}$ (1.53) and $\mathrm{Na}_{2} \mathrm{O}+\mathrm{K}_{2} \mathrm{O}$ (5.33) (Table 2). 
Table 2

Ma jor (wt.\%) and trace element (ppm) abundances in Khalkhab-Neshveh samples.

\begin{tabular}{|c|c|c|c|c|c|c|c|c|c|c|c|c|c|c|c|}
\hline \multirow{2}{*}{$\begin{array}{l}\text { Rock type } \\
\text { Sample no. }\end{array}$} & \multicolumn{5}{|c|}{ Quartz monzogabbro } & \multicolumn{5}{|c|}{ Qz monzodiorite } & \multicolumn{3}{|c|}{ Granodiorite } & \multicolumn{2}{|c|}{ Granite } \\
\hline & SK11 & SK 42 & SK18 & SK5 & SK64 & SK58 & SN 10 & SK62 & SN11 & SK66 & SN17 & SN15 & SN44 & SN52 & SK56 \\
\hline $\mathrm{SiO}_{2}$ & 52.1 & 52.2 & 53.2 & 54.7 & 55.5 & 55.1 & 56.5 & 56.7 & 59.6 & 60.8 & 62.5 & 62.7 & 65.1 & 69.4 & 71.2 \\
\hline $\mathrm{TiO}_{2}$ & 0.93 & 1.01 & 0.82 & 0.87 & 0.8 & 0.74 & 0.73 & 0.75 & 0.71 & 0.71 & 0.51 & 0.57 & 0.49 & 0.32 & 0.33 \\
\hline $\mathrm{Al}_{2} \mathrm{O}_{3}$ & 17.05 & 14.9 & 16.25 & 17.85 & 16.45 & 17.95 & 17.1 & 16.55 & 16.7 & 15.7 & 15.45 & 16.15 & 14.8 & 13.8 & 12.7 \\
\hline $\mathrm{Fe}_{2} \mathrm{O}_{3}$ & 11.1 & 12.85 & 10.3 & 8.96 & 8.59 & 8.95 & 8.66 & 9.38 & 7.66 & 7.66 & 5.07 & 6.03 & 3.89 & 3.05 & 3.05 \\
\hline $\mathrm{MnO}$ & 0.19 & 0.29 & 0.3 & 0.22 & 0.12 & 0.11 & 0.14 & 0.2 & 0.14 & 0.14 & 0.13 & 0.15 & 0.05 & 0.07 & 0.05 \\
\hline $\mathrm{MgO}$ & 4.08 & 4.11 & 4.43 & 2.32 & 3.75 & 3.1 & 3.26 & 3.6 & 2.48 & 2.41 & 2.05 & 1.78 & 1.52 & 1.1 & 0.6 \\
\hline $\mathrm{CaO}$ & 7.44 & 7.71 & 6.33 & 6.83 & 7.66 & 7.06 & 7.16 & 7.71 & 5.89 & 5.19 & 3.38 & 4.81 & 4.84 & 2.27 & 1.58 \\
\hline $\mathrm{Na}_{2} \mathrm{O}$ & 3.39 & 2.42 & 3.1 & 4.09 & 3.82 & 3.68 & 3.23 & 3.14 & 3.59 & 3.44 & 3.64 & 3.49 & 3.47 & 3.06 & 2.56 \\
\hline $\mathrm{K}_{2} \mathrm{O}$ & 1.48 & 1.88 & 2.1 & 1.62 & 1.21 & 1.93 & 1.85 & 1.76 & 2.31 & 2.38 & 3.46 & 2.73 & 2.9 & 4.19 & 5.14 \\
\hline $\mathrm{P}_{2} \mathrm{O}_{5}$ & 0.23 & 0.26 & 0.15 & 0.43 & 0.25 & 0.26 & 0.23 & 0.22 & 0.2 & 0.22 & 0.15 & 0.19 & 0.15 & 0.09 & 0.11 \\
\hline Total & 98 & 97.6 & 97 & 97.9 & 98.2 & 98.9 & 98.9 & 100 & 99.3 & 98.7 & 96.3 & 98.6 & 97.2 & 97.4 & 97.3 \\
\hline v & 353 & 426 & 338 & 208 & 295 & 226 & 241 & 269 & 194 & 188 & 89 & 128 & 76 & 47 & 52 \\
\hline $\mathrm{Cr}$ & 30 & 10 & 20 & 10 & 30 & 10 & 20 & 30 & 10 & 10 & 10 & 10 & 10 & 10 & 10 \\
\hline $\mathrm{Ni}$ & 16 & 13 & 14 & 6 & 13 & 7 & 14 & 11 & 8 & 8 & 5 & 8 & 5 & 5 & 6 \\
\hline Co & 30.3 & 32.4 & 29.8 & 15.8 & 17.7 & 18.5 & 3.8 & 24.4 & 17.4 & 16.6 & 8 & 12.8 & 5 & 4 & 5.5 \\
\hline $\mathrm{Cu}$ & 264 & 121 & 451 & 36 & 33 & 49 & 53 & 52 & 48 & 29 & 22 & 47 & 5 & 8 & 25 \\
\hline $\mathrm{Zn}$ & 104 & 120 & 169 & 66 & 49 & 45 & 51 & 92 & 75 & 65 & 80 & 76 & 23 & 44 & 40 \\
\hline Ga & 17.9 & 16.9 & 17.3 & 18 & 17.1 & 18.1 & 17.5 & 16.7 & 17.7 & 16.3 & 15 & 16.2 & 14.4 & 13.2 & 12.9 \\
\hline $\mathrm{Sn}$ & 1 & 1 & 1 & 1 & 1 & 1 & 2 & 1 & 3 & 2 & 1 & 1 & 2 & 1 & 1 \\
\hline W & 1 & 1 & 1 & 1 & 1 & 1 & 1 & 2 & 2 & 3 & 2 & 2 & 1 & 1 & 1 \\
\hline $\mathrm{Ba}$ & 341 & 422 & 554 & 361 & 247 & 495 & 465 & 428 & 548 & 605 & 701 & 675 & 759 & 808 & 500 \\
\hline $\mathrm{Sr}$ & 391 & 336 & 369 & 403 & 347 & 589 & 503 & 383 & 424 & 394 & 347 & 449 & 353 & 248 & 146 \\
\hline $\mathrm{Rb}$ & 33.1 & 38.6 & 46.1 & 40.4 & 27.9 & 40.4 & 48.7 & 43.3 & 60.9 & 56 & 74.2 & 71.4 & 38.1 & 90.8 & 201 \\
\hline $\mathrm{Nb}$ & 4.4 & 5.5 & 4.3 & 6.1 & 4.9 & 4.3 & 4.8 & 4.6 & 6.6 & 6.6 & 7.9 & 6.6 & 7.4 & 8.7 & 9.9 \\
\hline $\mathrm{Y}$ & 22.4 & 25.3 & 21.3 & 27.7 & 23.9 & 21.7 & 20.9 & 25 & 23 & 25.7 & 21.6 & 20.4 & 18.4 & 16.2 & 23.2 \\
\hline $\mathrm{Zr}$ & 81 & 81 & 79 & 121 & 94 & 72 & 83 & 95 & 119 & 145 & 134 & 121 & 145 & 124 & 189 \\
\hline Cs & 1.25 & 0.67 & 0.87 & 0.68 & 0.74 & 1.19 & 1.95 & 1.5 & 2.34 & 1.88 & 1.49 & 1.22 & 0.4 & 1.47 & 3.07 \\
\hline $\mathrm{Hf}$ & 2.4 & 2.8 & 2.4 & 3.6 & 2.9 & 2.2 & 2.4 & 2.8 & 3.5 & 4.2 & 3.8 & 3.6 & 4.1 & 3.8 & 6.2 \\
\hline Ta & 0.3 & 0.4 & 0.3 & 0.4 & 0.3 & 0.3 & 0.3 & 0.3 & 0.5 & 0.4 & 0.5 & 0.5 & 0.5 & 0.7 & 0.8 \\
\hline Th & 3.35 & 5.69 & 3.39 & 5.41 & 4.02 & 2.72 & 3.17 & 3.56 & 5.11 & 4.62 & 5.89 & 5.55 & 5.91 & 8.42 & 21.1 \\
\hline $\mathrm{U}$ & 0.99 & 1.38 & 1.02 & 1.64 & 1.15 & 0.73 & 0.71 & 1.02 & 1.23 & 1.47 & 1.3 & 1.43 & 1.56 & 1.78 & 5.18 \\
\hline La & 10.9 & 12.9 & 9.6 & 14.1 & 11.5 & 13.7 & 14 & 11.8 & 15.3 & 16.5 & 16.8 & 24.2 & 16 & 19.7 & 19.9 \\
\hline $\mathrm{Ce}$ & 22.3 & 26.4 & 20 & 28.5 & 23.7 & 28.2 & 28.4 & 24.5 & 30.8 & 33.3 & 32.6 & 45.7 & 31.6 & 34.9 & 38.1 \\
\hline Pr & 2.97 & 3.57 & 2.62 & 3.73 & 3.07 & 3.7 & 3.64 & 3.22 & 3.85 & 4.16 & 4.07 & 5.24 & 3.85 & 3.9 & 4.39 \\
\hline Nd & 12.9 & 14.5 & 11.2 & 15.9 & 13.3 & 15.4 & 14.9 & 13.5 & 15.4 & 16.8 & 16.2 & 19.3 & 14.9 & 14.2 & 16.3 \\
\hline $\mathrm{Sm}$ & 3.18 & 3.68 & 2.85 & 3.91 & 3.24 & 3.64 & 3.38 & 3.31 & 3.53 & 4.02 & 3.7 & 3.76 & 3.21 & 2.84 & 3.54 \\
\hline $\mathrm{Eu}$ & 0.97 & 1.06 & 0.93 & 1.2 & 0.95 & 1.02 & 0.99 & 1.05 & 0.94 & 1.04 & 0.91 & 0.95 & 0.88 & 0.6 & 0.51 \\
\hline Gd & 3.96 & 4.21 & 3.42 & 4.62 & 3.83 & 3.92 & 3.67 & 4.24 & 3.87 & 4.4 & 4.15 & 3.91 & 3.65 & 2.99 & 3.85 \\
\hline $\mathrm{Tb}$ & 0.61 & 0.72 & 0.57 & 0.75 & 0.64 & 0.62 & 0.59 & 0.69 & 0.62 & 0.69 & 0.64 & 0.56 & 0.55 & 0.46 & 0.63 \\
\hline Dy & 4.02 & 4.62 & 3.83 & 4.85 & 4.12 & 3.92 & 3.73 & 4.38 & 4 & 4.44 & 3.88 & 3.48 & 3.26 & 2.8 & 4.03 \\
\hline Ho & 0.83 & 0.94 & 0.81 & 0.98 & 0.87 & 0.75 & 0.77 & 0.93 & 0.8 & 0.94 & 0.83 & 0.71 & 0.69 & 0.6 & 0.85 \\
\hline $\mathrm{Er}$ & 2.35 & 2.74 & 2.48 & 2.99 & 2.68 & 2.24 & 2.18 & 2.67 & 2.45 & 2.76 & 2.41 & 2.12 & 2.12 & 1.89 & 2.57 \\
\hline $\operatorname{Tm}$ & 0.36 & 0.41 & 0.35 & 0.43 & 0.38 & 0.35 & 0.32 & 0.41 & 0.34 & 0.42 & 0.37 & 0.32 & 0.32 & 0.29 & 0.38 \\
\hline $\mathrm{Yb}$ & 2.35 & 2.56 & 2.34 & 2.65 & 2.47 & 2.18 & 2.24 & 2.62 & 2.39 & 2.68 & 2.44 & 2.14 & 2.16 & 2.06 & 2.65 \\
\hline $\mathrm{Lu}$ & 0.37 & 0.42 & 0.36 & 0.43 & 0.39 & 0.38 & 0.33 & 0.45 & 0.4 & 0.47 & 0.37 & 0.36 & 0.33 & 0.34 & 0.44 \\
\hline Mo & 2 & 2 & 3 & 2 & 2 & 2 & 2 & 2 & 2 & 2 & 2 & 2 & 2 & 2 & 2 \\
\hline $\mathrm{Pb}$ & 18 & 5 & 75 & 6 & 8 & 6 & 7 & 8 & 11 & 12 & 21 & 13 & 6 & 17 & 11 \\
\hline $\mathrm{Tl}$ & 0.5 & 0.5 & 0.5 & 0.5 & 0.5 & 0.5 & 0.5 & 0.5 & 0.5 & 0.5 & 0.5 & 0.5 & 0.5 & 0.5 & 0.5 \\
\hline $\mathrm{Na}_{2} \mathrm{O} / \mathrm{K}_{2} \mathrm{O}$ & 2.29 & 1.29 & 1.48 & 2.52 & 3.16 & 1.91 & 1.75 & 1.78 & 1.55 & 1.45 & 1.05 & 1.28 & 1.2 & 0.73 & 0.5 \\
\hline $\mathrm{Na}_{2} \mathrm{O}+\mathrm{K}_{2} \mathrm{O}$ & 4.87 & 4.3 & 5.2 & 5.71 & 5.03 & 5.61 & 5.08 & 4.9 & 5.9 & 5.82 & 7.1 & 6.22 & 6.37 & 7.25 & 7.7 \\
\hline $\mathrm{CaO} / \mathrm{Na}_{2} \mathrm{O}$ & 2.19 & 3.19 & 2.04 & 1.67 & 2.01 & 1.92 & 2.22 & 2.46 & 1.64 & 1.51 & 0.93 & 1.38 & 1.39 & 0.74 & 0.62 \\
\hline $\mathrm{Rb} / \mathrm{Sr}$ & 0.08 & 0.11 & 0.12 & 0.1 & 0.08 & 0.07 & 0.1 & 0.11 & 0.14 & 0.14 & 0.21 & 0.16 & 0.11 & 0.37 & 1.38 \\
\hline $\mathrm{Eu} / \mathrm{Eu}^{*}$ & 0.84 & 0.83 & 0.91 & 0.87 & 0.83 & 0.82 & 0.86 & 0.86 & 0.78 & 0.76 & 0.71 & 0.75 & 0.79 & 0.63 & 0.42 \\
\hline
\end{tabular}

The Khalkhab-Neshveh rocks have a wide range in $\mathrm{SiO}_{2}$ (52.1$71.2 \%$ ), $\mathrm{Fe}_{2} \mathrm{O}_{3}, \mathrm{MgO}, \mathrm{MnO}, \mathrm{CaO}, \mathrm{TiO}_{2}$ and $\mathrm{P}_{2} \mathrm{O}_{5}$ (Table 2). Most ma jor elements except $\mathrm{Al}_{2} \mathrm{O}_{3}, \mathrm{Na}_{2} \mathrm{O}$ and $\mathrm{K}_{2} \mathrm{O}$ show negative linear trends with increasing $\mathrm{SiO}_{2}$ (Fig. 6). $\mathrm{K}_{2} \mathrm{O}$ shows a descending trend, while $\mathrm{Al}_{2} \mathrm{O}_{3}, \mathrm{Na}_{2} \mathrm{O}$ have bent trends. $\mathrm{Na}_{2} \mathrm{O}$ is positive up to $62 \mathrm{wt} . \% \mathrm{SiO}_{2}$ and negative from this point onward.

In Harker diagrams (Fig. 7), Ba, Rb, Zr, Nb, and Ce show ascending linear trends, whereas $V$ and Co decrease with increasing silica content. Sr, Eu and Y follow curved trends that suggest these elements behaved incompatibly in the magmas that formed the quartz monzogabbro and quartz monzodiorite, and compatibly during the crystallization of granodiorite and granite.

The samples display similar chondrite-normalized REE patterns. They are characterized by LREE enrichment with $(\mathrm{La} / \mathrm{Sm})_{\mathrm{N}}=2.11-$
4.27 and weakly fractionated HREE with $(\mathrm{Gd} / \mathrm{Yb})_{\mathrm{N}}=1.16-1.46$, suggesting garnet-free sources (Wilson, 2007). The mafic to intermediate rocks have slight but very consistent negative Eu anomalies ( $\mathrm{Eu} / \mathrm{Eu}^{*}=0.91-0.82$ ), decreasing more markedly in the granodiorites to a minimum of 0.42 in a granite with $71 \mathrm{wt} . \%$ $\mathrm{SiO}_{2}$ (Fig. 8A).

These geochemical characteristics, with light-REE enrichment, positive $\mathrm{Pb}$ anomaly and the $\mathrm{Nb}-\mathrm{Ti}$ troughs on the spider diagram (Fig. 8B), are typical of calc-alkaline magmatism in active continental margins (Sun and McDonough, 1989). A marked Nb-Ta trough in primitive-mantle normalized trace element patterns has been ascribed to retention of these elements in mineral phases containing Ti (e.g., rutile) during dehydration of subducted oceanic crust or crustal contamination (Schmidt et al., 2006). 


\begin{tabular}{|c|c|c|c|c|c|c|c|c|c|c|c|c|c|c|}
\hline Sample & & $\mathrm{Rb} \mathrm{ppm}$ & Sr ppm & $\mathrm{Rb} / \mathrm{Sr}$ & ${ }^{87} \mathrm{Rb} /{ }^{86} \mathrm{Sr}$ & ${ }^{87} \mathrm{Sr} /{ }^{86} \mathrm{Sr}$ & $\left({ }^{87} \mathrm{Sr} /{ }^{86} \mathrm{Sr}\right)_{38}$ & Smppm & Nd ppm & $\begin{array}{l}\mathrm{Sm} / \\
\mathrm{Nd}\end{array}$ & ${ }^{147} \mathrm{Sm} /{ }^{144} \mathrm{Nd}$ & ${ }^{143} \mathrm{Nd} /{ }^{144} \mathrm{Nd}$ & $\varepsilon \mathrm{Nd}_{38}$ & $T_{\bullet M}{ }^{a}$ \\
\hline \multicolumn{15}{|c|}{ Khalkhab-Neshveh } \\
\hline SS-61 & Granite & 20.2 & 222.7 & 0.091 & 0.262 & 0.705009 & 0.704860 & 3.70 & 12.29 & 0.301 & 0.182 & 0.512748 & +2.2 & 697 \\
\hline SN-15 & Granodiorite & 69.8 & 443.6 & 0.157 & 0.455 & 0.704829 & 0.704570 & 3.47 & 17.59 & 0.197 & 0.119 & 0.512765 & +2.9 & 638 \\
\hline SS-23 & Granodiorite & 35.0 & 230.8 & 0.152 & 0.439 & 0.704978 & 0.704728 & 5.06 & 20.15 & 0.251 & 0.152 & 0.512768 & +2.8 & 647 \\
\hline SK-47 & Qz monzodiorite & 107.5 & 356.0 & 0.302 & 0.873 & 0.705033 & 0.704536 & 3.16 & 13.72 & 0.231 & 0.139 & 0.512825 & +3.9 & 536 \\
\hline SK-18 & Qz monzogabbro & 46.3 & 373.3 & 0.124 & 0.359 & 0.704901 & 0.704697 & 2.71 & 10.04 & 0.270 & 0.163 & 0.512797 & +3.3 & 599 \\
\hline SS-2 & Qz monzogabbro & 3.7 & 400.2 & 0.009 & 0.027 & 0.704853 & 0.704838 & 1.76 & 6.16 & 0.286 & 0.173 & 0.512770 & +2.7 & 653 \\
\hline \multicolumn{15}{|l|}{ Selijerd $^{\mathrm{b}}$} \\
\hline R.2.18 & Granite & 125.9 & 430.6 & 0.292 & 0.845 & 0.704955 & 0.704475 & & & & & & & \\
\hline R.2.1 & Diorite & 3.7 & 401.3 & 0.009 & 0.027 & 0.704759 & 0.704744 & & & & & & & \\
\hline R.2.21 & Diorite & 31.4 & 398.7 & 0.079 & 0.228 & 0.705166 & 0.705037 & & & & & & & \\
\hline
\end{tabular}

a $T_{0 M}$ is two-stage mantle model age after DePaolo et al. (1991).

b Data from Ghasemi et al. (2008).

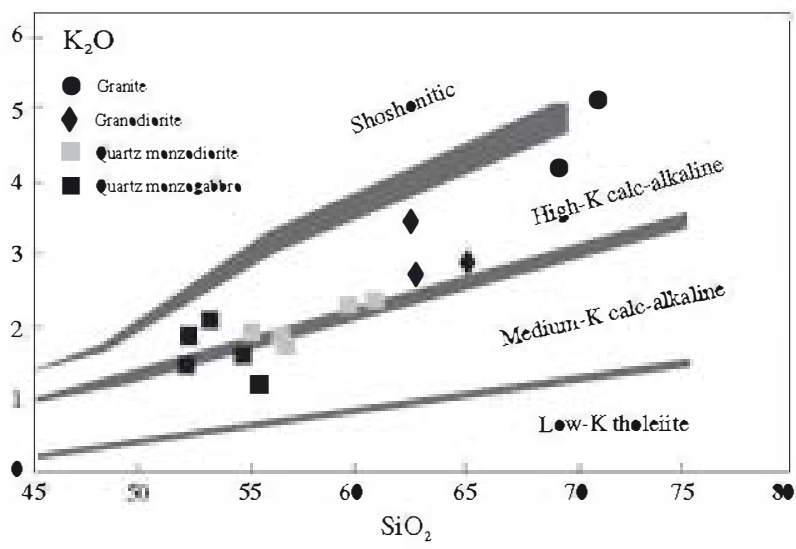

Fig. 5. Plot of $\mathrm{K}_{2} \mathrm{O}$ vs. $\mathrm{SiO}_{2}$ showing the calc-alkaline nature of the KhalkhabNeshveh rocks (Rickwood, 1989).

\section{Isotope data}

Six whole-rock samples ranging from quartz monzogabbro to granodiorite were analysed for $\mathrm{Sr}$ and $\mathrm{Nd}$ isotope composition (Table 3). Measured ${ }^{87} \mathrm{Sr} /{ }^{86} \mathrm{Sr}$ ratios all fall within the narrow range $0.7048-0.7050$, and measured ${ }^{143} \mathrm{Nd} /{ }^{144} \mathrm{Nd}=0.51275-0.51283$. The $\mathrm{Rb}, \mathrm{Sr}, \mathrm{Sm}$ and $\mathrm{Nd}$ concentrations obtained by ICP are used to calculate initial compositions assuming a mid-Eocene age of $38 \mathrm{Ma}$. Age corrections are small, so that the mean initial ${ }^{87} \mathrm{Sr} /{ }^{86} \mathrm{Sr}$ of 0.7047 is insensitive to uncertainties in either age or $\mathrm{Rb} / \mathrm{Sr}$ ratio and indicates derivation from a homogeneous magma derived from a source with no long-term enrichment in $\mathrm{Rb}$ compared to Sr. Initial $\varepsilon N d$ values average +3.0 , but are slightly more variable $(+2.2$ to +3.9 , Table 3 , Fig. 9). The positive values are consistent with a relatively lithophile-depleted source rather than very old continental crust with low $\mathrm{Sm} / \mathrm{Nd}$ ratios, which is also confirmed by the initial ${ }^{87} \mathrm{Sr} /{ }^{86} \mathrm{Sr}$ values. The two-stage model $\mathrm{Nd}$ ages of around 650 Ma may be considered as a maximum for mantle-separation of material with an average crustal $\mathrm{Sm} / \mathrm{Nd}$ ratio. The initial isotopic compositions of $\mathrm{Sr}$ and $\mathrm{Nd}$ of other plutons near the studied area are also plotted in Fig. 9. It seems that the initial ${ }^{87} \mathrm{Sr} /{ }^{86} \mathrm{Sr}$ increases with decreasing ages of plutons, which might result from enrichment of the mantle beneath Central Iran during the continuous subduction of Neotethyan Ocean beneath Iranian plate, or a switch in the source of intermediate (mostly gabbroic) rocks from mantle to lower crust.

\section{Discussion}

7.1. Petrological and geochemical variations in the Khalkhab-Neshveh rocks

Many previous workers have shown that mineralogical and geochemical variations in magmatic suites from volcanic arcs can be produced by either magma mixing (e.g., Popov et al., 1999; Bea et al., 2005) or assimilation-fractional crystallization processes (DePaolo, 1981; Spera and Bohrson, 2001; Thompson et al., 2002; Kuritani et al., 2005). These hypotheses, however, may be limited by the isotope data. The constant and low initial ${ }^{87} \mathrm{Sr} /{ }^{86} \mathrm{Sr}$ ratio throughout the monzogabbro-granodiorite sequence precludes mixing involving upper crustal material and is clearly most consistent with fractionation from a single well-mixed parent magma, or magmas derived by variable partial melting from a single homogenous source. The fractionation process can be further tested by the field, petrographic and geochemical data.

Clinopyroxene is dominant mafic mineral in the quartz monzogabbro, but it is subordinate in the quartz monzodiorite and totally disappears in the granodiorite and granite. Green hornblende occurs as subhedral to euhedral crystals in most samples from the quartz monzodiorite to felsic rocks, sometimes partly replaced by actinolite and biotite. Thus with increasing content of biotite and quartz, clinopyroxene may disappear or give way to hornblende and biotite. Apatite is not ubiquitous but appears as euhedral crystals of variable size; its modal abundance is less than $0.7 \%$ in the quartz monzodiorite and decreases with increasing silica. K-feldspar and quartz occur throughout; they are interstitial in the quartz monzogabbro and their grain-size and abundances increase from these rocks to the granites. Given the wide range of compositions, the lack of disequilibrium minerals, and the isotope data presented below, these progressive changes are interpreted as due to crystal fractionation rather than mixing between a mantle-derived basaltic magma and a crustal granitic magma; to this we may add the gradational internal contacts and the lack of mafic enclaves in the more evolved rocks.

Magma mixing and/or mingling and assimilation has frequently been observed in calc-alkaline magmatic arc complexes (e.g., Chappell, 1996) but cannot be invoked to account for the large scale compositional variations seen in the Khalkhab-Neshveh pluton. Although magma mixing can result in linear variations in Harker diagrams, it cannot explain the inflected trends shown by $\mathrm{Na}_{2} \mathrm{O}, \mathrm{Al}_{2} \mathrm{O}_{3}, \mathrm{Sr}, \mathrm{Eu}$ and $\mathrm{Y}$ (Figs. 6 and 7). Finally, minor and trace element abundances plotted in multi-element and rare earth element diagrams (Fig. 8) show similar and smooth 

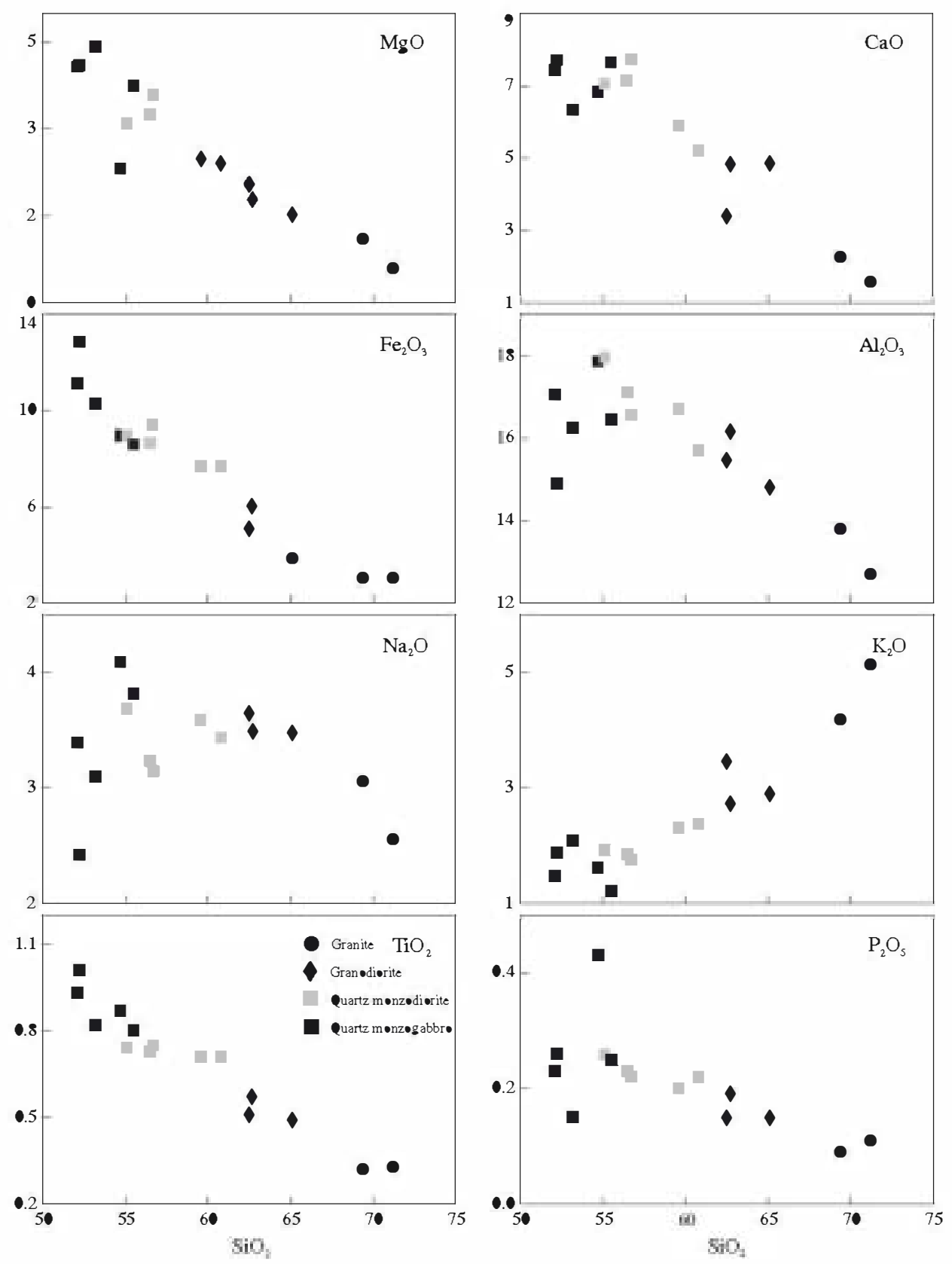

Fig. 6. Selected major oxides vs. $\mathrm{SiO}_{2}$ (wt.\%) contents for the Khalkhab-Neshveh rocks.

progression from one rock type to the next within the pluton, which is interpreted as resulting from crystal fractionation of the quartz monzogabbros.

Thus we conclude that petrological and geochemical variations in these rocks have resulted from magmatic differentiation (partial melting or crystal fractionation). Crystal fractionation is more effective at fractionating compatible elements, and discrimination between these two mechanisms may be based on the behaviour of trace elements in a logarithmic plot of an incompatible element against a compatible element, where they have very different bulk partition coefficients. In such a diagram, liquids produced by crystal fractionation give a straight line with strong decrease in the compatible element whereas the concentration of the incompatible element $(D \ll 1)$ increases slowly; the opposite relationships apply to liquids produced by partial melting (Cocherie, 1986). Fig. 7 shows that V content decreases with increasing
$\mathrm{SiO}_{2}$, thus demonstrating its compatible behaviour, whereas positive correlations point to the incompatible behaviour of $\mathrm{Rb}$ and Ba. Fig. 10 shows log-log plots for Rb and Ba (incompatible) vs. $\mathrm{V}$ (compatible). The trends shown are sub-vertical with drastic reduction of the concentration of compatible element (V) throughout the quartz monzogabbro to granodiorite sequence, and the incompatible element contents only increasing rapidly in the granites. This suggests that the main mechanism of differentiation is crystal fractionation.

Although the Khalkhab-Neshveh rocks have various petrographic and mineralogical characteristics, they show similar REE patterns, especially in the HREE. The widely varying concentrations of $\mathrm{Nb}$, Ta and Th (4.3-9.9 ppm, 0.3-0.8 ppm, 2.7-21.1 ppm, respectively), almost similar initial ${ }^{87} \mathrm{Sr} /{ }^{86} \mathrm{Sr}$ and ${ }^{144} \mathrm{Nd} /{ }^{143} \mathrm{Nd}$ ratios and gradual changes in Eu-anomaly are also key features. The hypothesis that provides the most satisfactory explanation of these 

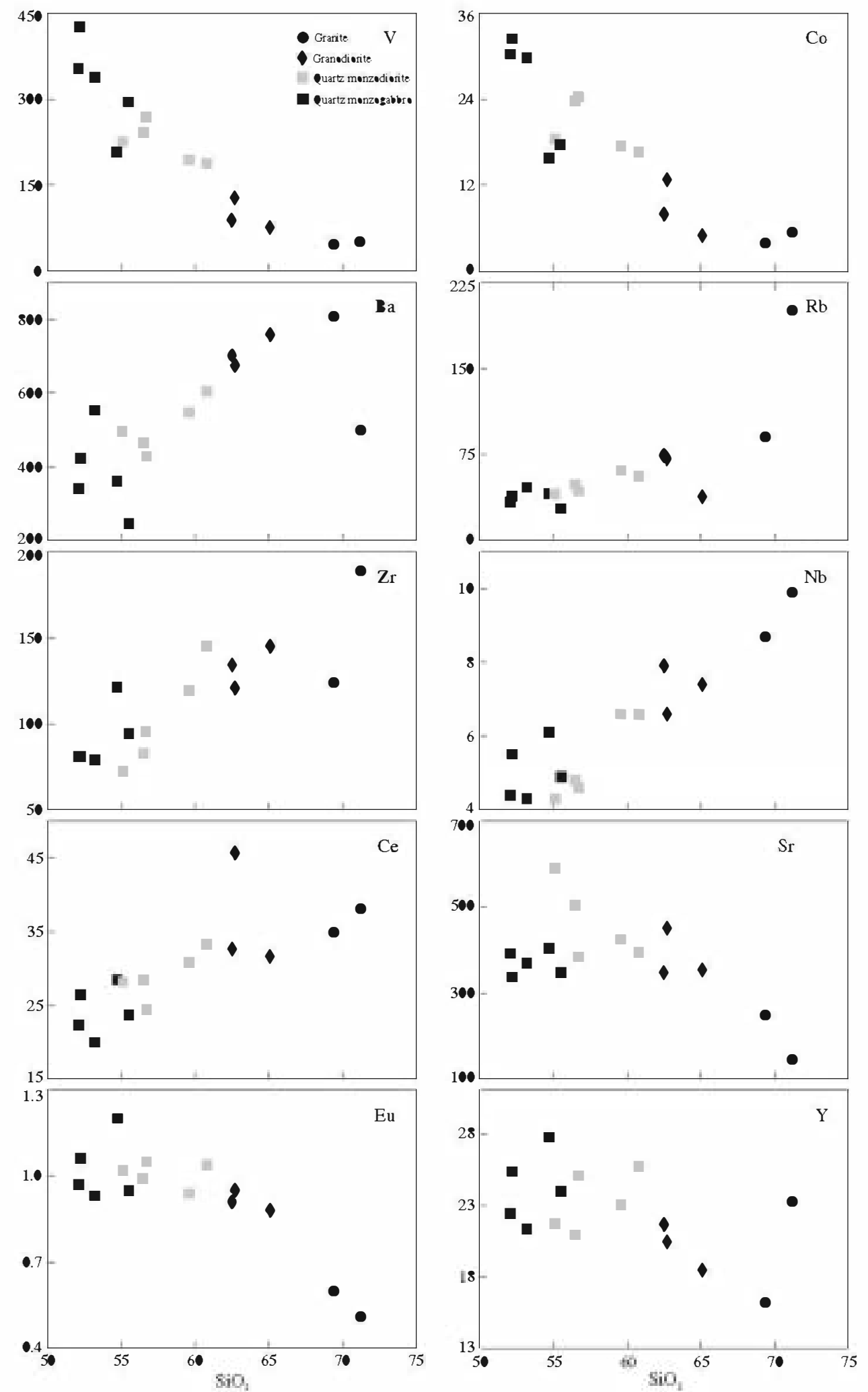

Fig. 7. Selected trace elements (ppm) vs. $\mathrm{SiO}_{2}$ (wt.\%) contents for the Khalkhab-Neshveh rocks.

features is a crystal fractionation model, in which all the rocks were derived from a parental magma via the fractionation. The granitic rocks of the pluton are the most fractionated rocks, enriched in large-ion lithophile elements ( $R b, T h, U$, and $K$ ) and depleted in $\mathrm{Sr}, \mathrm{P}$ and Ti compared to the others.
The essentially co-magmatic nature of the entire range of rock types in the Khalkhab-Neshveh pluton contrasts with the conclusion of Aghazadeh et al. (2010) for the Khankandi pluton in the Alborz Mountains of NW Iran, who distinguish two magmatic series. A granodiorite-granite stage was intruded by a 

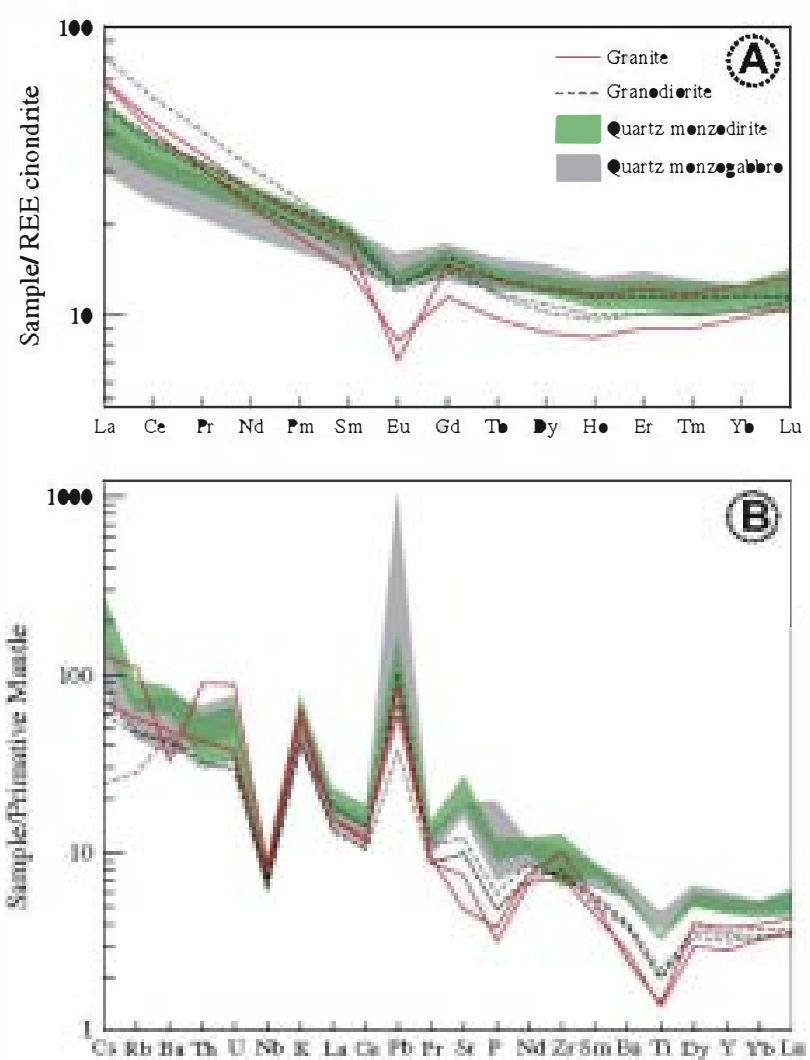

Fig. 8. Chondrite-normalized rare earth element plot of the Khalkhab-Neshveh rocks (A). Primitive mantle nor malized wace element patterns (B). Studied samples are depleted in the incompatible high field strength elements such as $\mathrm{Nb}$ and $\mathrm{Ti}$ which are relative to the primitive mantle. Normalization values after Boynton (1984) and Sun and McDonough (1989), respectively.

younger, shoshonitic, gabbro-monzonite association. Despite common initial ${ }^{87} \mathrm{Sr} /{ }^{86} \mathrm{Sr}$ and $\varepsilon N d$ values for both series $(0.7045-0.7047$ and 1.46-1.89, respectively), they ascribed the granodiorites to melting of 'subducted mélange' and the gabbro-monzonite series to variable partial melting of metasomatized mantle. The
Khalkhab-Neshveh rocks differ very significantly from those of the Khankandi pluton in several respects: (1) their degree of $\mathrm{K}_{2} \mathrm{O}$ enrichment is less and they do not contain monzonites, defined either mineralogically or chemically (see Fig. 11), (2) they consistently fall within the calc-alkaline fields in discrimination diagrams such as those of Rickwood (1989; Fig. 5) and Pecerillo and Taylor (1976), (3) they do not show the same silica gap (61-68\%) that separates their two series, and (4) REE patterns in Khalkhab-Neshveh (Fig. 8A) are much less fractionated and show a smooth progression throughout, with development of a negative Eu anomaly in the granites not seen in the Khankandi rocks. Thus we see no evidence for more than one source of the Khalkhab-Neshveh magmas. This may reflect a change of tectonic scenario in time and between the northern Alborz magmatic belt and more southerly UrumiehDokhtar magmatic arc. It is also notable that the two plutons have very different country rock settings: Khalkhab-Neshveh was intruded through continental crust with a Precambrian basement, Khankandi through a rifted region with old oceanic crust.

\subsection{Mineral controls on fractionation}

A general crystal fractionation trend within the representative samples is indicated by decreasing $\mathrm{TiO}_{2}, \mathrm{MgO}, \mathrm{Fe}_{2} \mathrm{O}_{3}, \mathrm{CaO}$ and $\mathrm{P}_{2} \mathrm{O}_{5}$ concentrations, and increasing $\mathrm{K}_{2} \mathrm{O}$ together with most of the trace elements, e.g., Ba, $\mathrm{Rb}, \mathrm{La}$ and $\mathrm{Ce}$. Some elements such as $\mathrm{Na}_{2} \mathrm{O}, \mathrm{Al}_{2} \mathrm{O}_{3}, \mathrm{Sr}$ and $\mathrm{Y}$ define broken or curved trends, a characteristic that allows us to discount their derivation by mixing and/or mingling mechanisms, and instead indicates that they result from crystal fractionation. In order to determine the magmatic evolution of Khalkhab-Neshveh pluton, the modal mineralogical and chemical compositions are used to model the role of minerals leading to chemical variations in the evolving magma.

\subsubsection{Clinopyroxene}

The average mode of clinopyroxene is $23 \%$ in the quartz monzogabbro, falling to zero in the granite (Table 1). At the same time, $\mathrm{CaO}$ decreases (Fig. 6), suggesting removal of Ca-rich phases. Three calcium bearing minerals in the Khalkhab-Neshveh rocks are plagioclase, clinopyroxene and hornblende. $\mathrm{Sr}$ is a compatible trace element in plagioclase but not in clinopyroxene, so that fractionation of plagioclase causes decreasing $\mathrm{Sr}$ with increasing

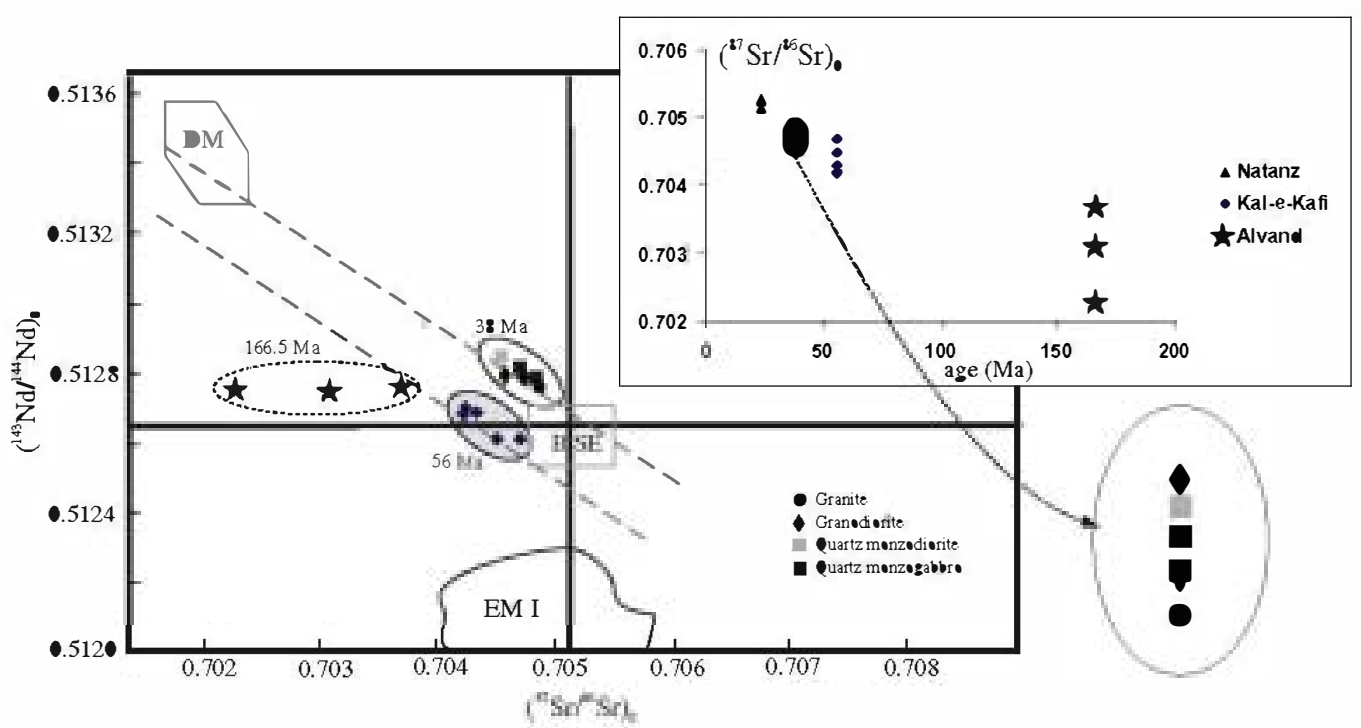

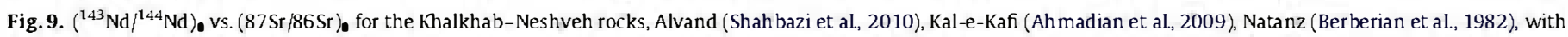

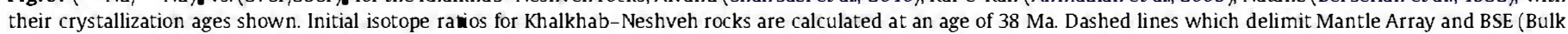
Silicate Earth) are after Rollinson (1993). 


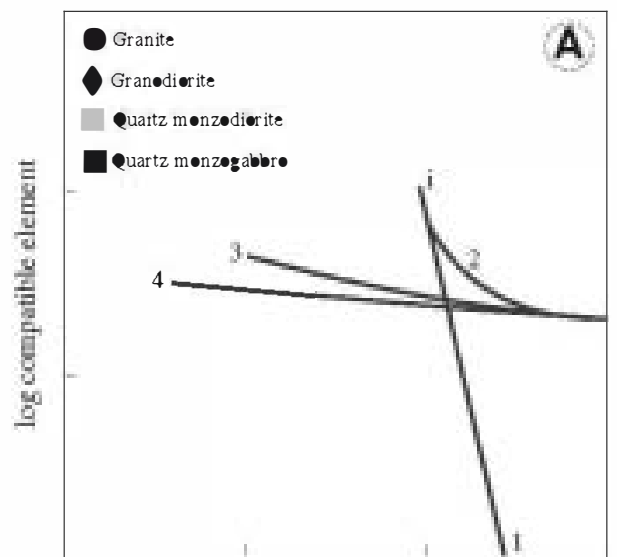

$\log$ incompatible element
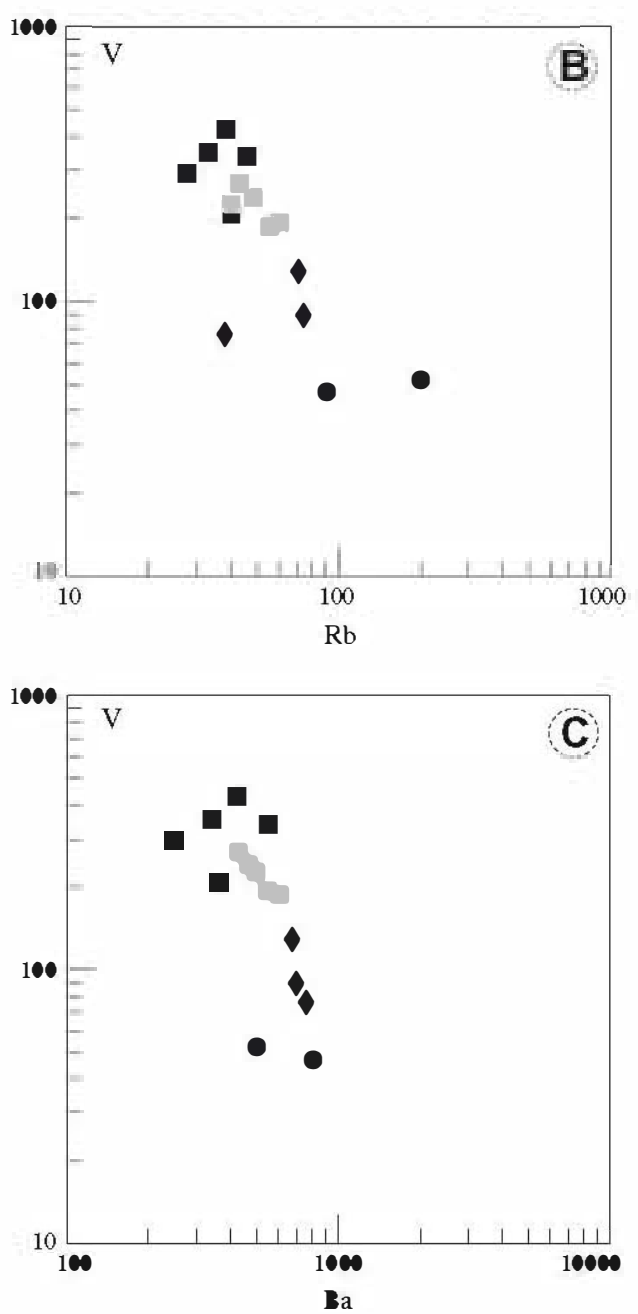

Fig. 10. A: Logarithmic evolution of concentrations for an incompatible element vs. a compatible element during crystal fractionation (1), batch parial melting (2) aggregate melting or fractional fusion with extraction of the mixed melts (3) and fractional fusion with continual removing of the melt formed (4). (i) Is the initial material (Cocherie, 1986). B and C are plots for the Khalkhab-Neshveh rocks, showing near-vertical trends that suggest the main mechanism of differentiation is crystal fractionation.

silica content (Wilson, 2007). In the Sr vs. MgO plot (Fig. 12A), Sr increases with increasing $\mathrm{MgO}$ up to $3.1 \mathrm{wt} \%$ (corresponding to $55 \mathrm{wt} . \% \mathrm{SiO}_{2}$ ) and then decreases. Since there is no hornblende in the rocks with $\mathrm{SiO}_{2}$ less than 55 wt.\% (Table 1), it seems that

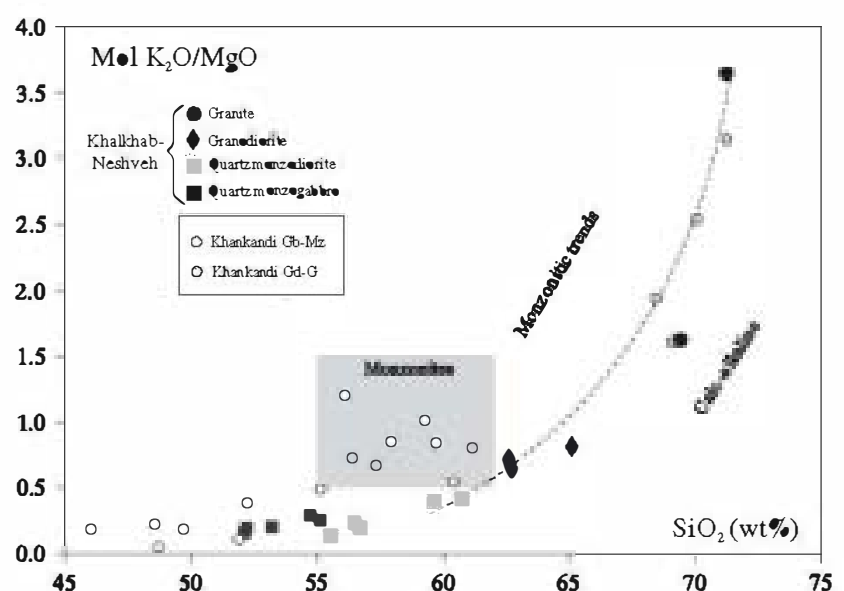

Fig. 11. Plot of molar $\mathrm{K}_{2} \mathrm{O} / \mathrm{MgO}$ vs. $\mathrm{SiO}_{2}$, used by Aghazadeh et al. (2010) to define the monzonitic/shoshonitic nature of the gabbro-monzonite series (Gb-Mz) of the hhankandi pluton. Data for the Khalkhab-Neshveh pluton fall completely outside the monzonite field as shown and, like the granodiorite-granites series of hankandi (Gd-G), predominantly in the calc-alkaline field. NB the (approximate) boundary between the fields has not been extended below $58 \% \mathrm{SiO}_{2}$ where we consider it to be meaningless.
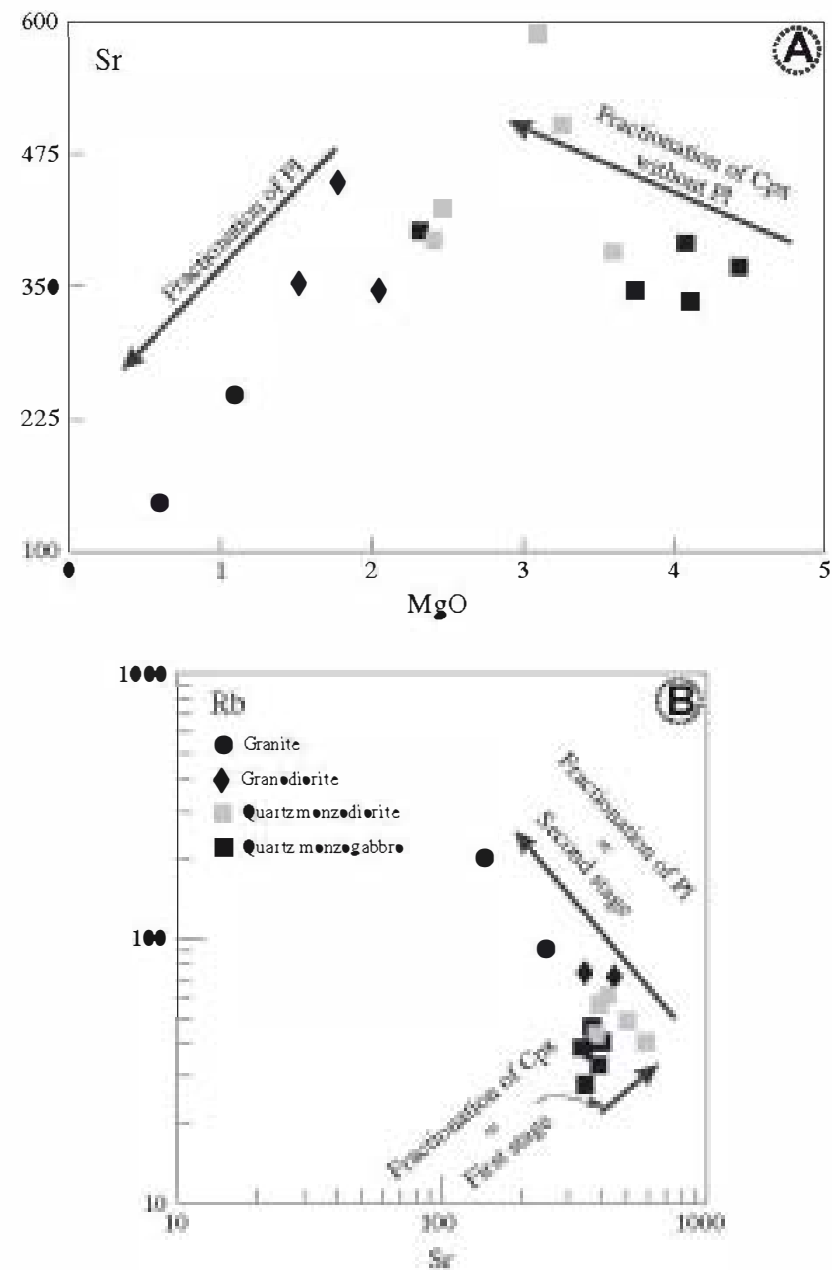

Fig. 12. (A), Sr vs. MgO plot showing that as Mg decreases, Sr increases. This relationship suggests plagioclase did not fractionate together with clinopyroxene in the rocks with $\mathrm{MgO}>3.1 \mathrm{wt} . \%$; if it had, $\mathrm{Sr}$, a compatible element in plagioclase, would decrease as MgO decreases (Wilson, 2007). (B), Rb vs. Sr diagram (logarithmic scale) showing the variation of halkhab-Neshveh samples (solid vectors are Rayleigh fractionation trends after Klimm et aI., 2008). Abbreviations are after Kretz (1983). 
clinopyroxene had the main role in decreasing concentrations of, e.g., $\mathrm{MgO}, \mathrm{Fe}_{2} \mathrm{O}_{3}, \mathrm{CaO}$ in the rocks with $\mathrm{MgO}>3.1$ wt.\%. In the rocks with $\mathrm{MgO}<3.1$ wt.\%, magmatic evolution could have been controlled by fractionation of clinopyroxene, plagioclase and hornblende.

In the log-log diagram of Rb vs. Sr (Fig. 12B, following Klimm et al., 2008), it appears that $\mathrm{Sr}$ concentration increases from about 350 to $590 \mathrm{ppm}$ as $\mathrm{Rb}$ increases to about $40 \mathrm{ppm}$ in the quartz monzodiorite, and then decreases to $150 \mathrm{ppm}$ in the Rb-rich granite. This can be explained by crystallization of clinopyroxene in the early stages followed by crystallization of the plagioclase, clinopyroxene and hornblende together in the later stage.

\subsubsection{Homblende}

Hornblende appears in the rocks with $\mathrm{SiO}_{2}>55$ wt.\%(Table 1); its mode increases from about 7 to $16.3 \%$ in the quartz monzodiorite, and then decreases to $\sim 2.3 \%$ in the granite. $\mathrm{Y}$ and $\mathrm{Yb}$ are commonly incompatible elements when garnet and hornblende are absent (Green, 1980; Winter, 2001). A significant decrease in Dy/Yb ratio with increasing silica is attributable to removal of hornblende and titanite (Davidson et al., 2007). In the Khalkhab-Neshveh rocks, Y concentration and Dy/Yb ratio remain fairly constant up to $62 \mathrm{wt} . \%$ $\mathrm{SiO}_{2}$ and then decrease, indicating the onset of hornblende and/or titanite fractionation (Figs. 7 and 13A). The data in Fig. 13B display a combined vector of hornblende and plagioclase fractionation, suggesting that both played a significant role during magmatic
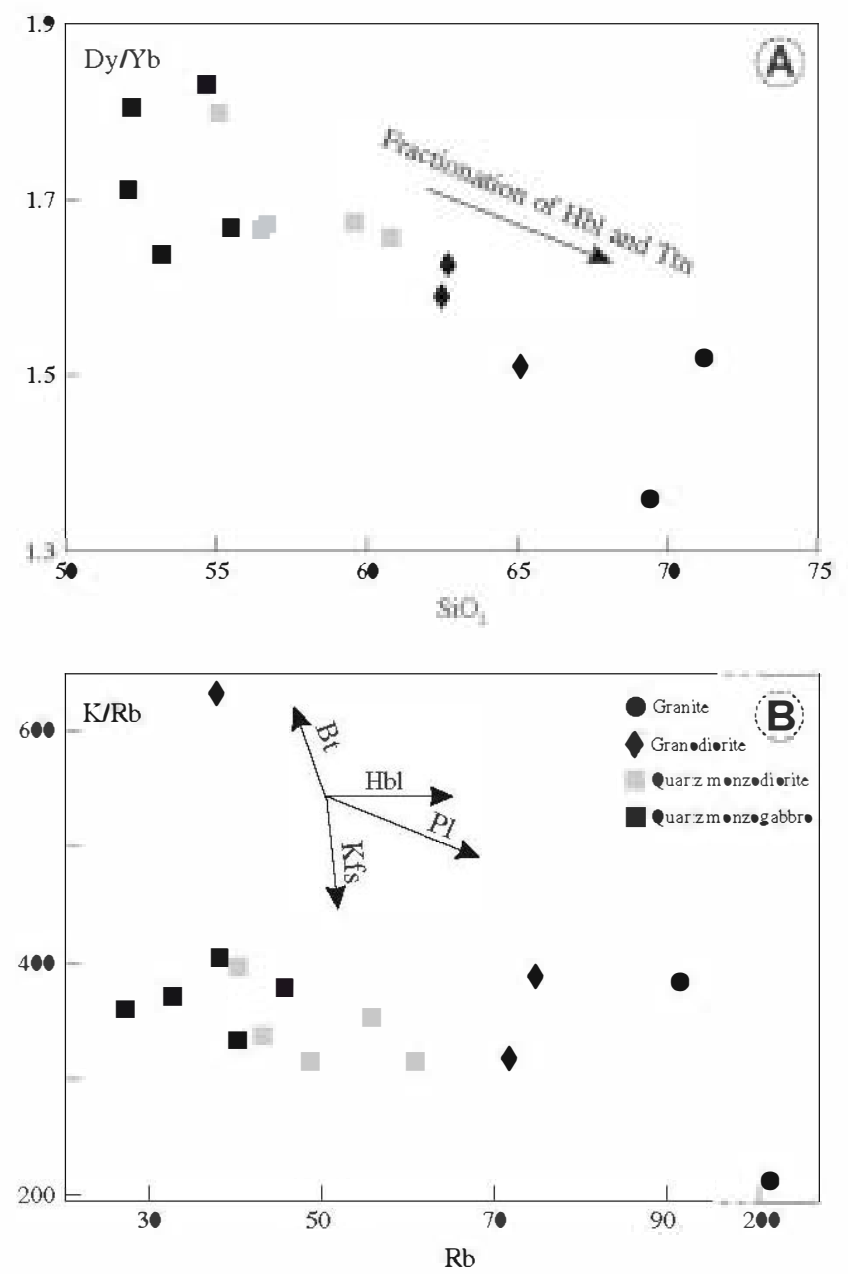

Fig. 13. The Khalkhab-Neshveh rocks follow the fractionated wends of hornblende on the Dy/Yb vs. $\mathrm{SiO}_{2}$ (A; after Davidson et aI., 2007) and $\mathrm{K} / \mathrm{Rb}$ vs. Rb diagrams (B). Abbreviations are after Kretz (1983). differentiation. Considering the modal mineralogical compositions and geochemical results, hornblende fractionation only played a role in the formation of rocks with more than $62 \mathrm{wt} . \% \mathrm{SiO}_{2}$ and consequently caused decrease of, e.g., $\mathrm{CaO}, \mathrm{MgO}$ and $\mathrm{FeO}$ in the magma.

\subsubsection{Feldspars}

The role of plagioclase is best examined through $\mathrm{Na}_{2} \mathrm{O}, \mathrm{Sr}$ and $\mathrm{Eu}$ trends in the representative samples. $\mathrm{Na}_{2} \mathrm{O}$ shows an inflected trend with increasing silica content, increasing up to 55 wt.\% $\mathrm{SiO}_{2}$ and then decreasing. Sr and Eu substitute for $\mathrm{Ca}$ and $\mathrm{Na}$ in plagioclase (but not in clinopyroxene); they have inflected trends in these samples that mimic that of $\mathrm{Na}_{2} \mathrm{O}$. These trends can be interpreted as indicating that plagioclase fractionation was more important in the formation of rocks with $\mathrm{SiO}_{2}>\sim 55 \mathrm{wt}$ \% compared to the rocks $\mathrm{SiO}_{2}<55 \mathrm{wt} . \%$ (petrographic observations show that there is no significant change in the proportion of plagioclase up to this point, Table 1). This is also the only reasonable explanation for the development of negative $\mathrm{Eu}$ anomalies in the granites. Thus plagioclase would have had no effect on $\mathrm{CaO}, \mathrm{Na}_{2} \mathrm{O}$ and $\mathrm{Al}_{2} \mathrm{O}_{3}$ in the less siliceous rocks.

K-feldspar and biotite have higher partition coefficients for Ba compared to other common minerals; similarly plagioclase has higher or similar partition coefficients for Sr than the ma jor minerals in andesitic to dacitic and rhyolitic magmas, respectively (see Rollinson, 1993). Hence the Ba/Sr ratio will help to identify the relative roles of $\mathrm{K}$-feldspar and plagioclase, since it increases with precipitation of plagioclase from the magma, but decreases when K-feldspar and biotite start to precipitate. In the Khalkhab-Neshveh rocks, $\mathrm{Ba} / \mathrm{Sr}$ is constant up to $55 \mathrm{wt} . \% \mathrm{SiO}_{2}$ and then increases, showing the effect of plagioclase precipitation (Fig. 14). Ba concentration increases with increasing $\mathrm{SiO}_{2}$ without any inflection, suggesting that $\mathbf{K}$-feldspar and biotite are late-crystallized minerals and/or sank very slowly in the co-existing melt during magmatic evolution (Wyborn et al., 2001). Essentially constant $\mathrm{K} / \mathrm{Rb}$ ratios (Fig. 13B) and the positive correlation between $\mathrm{K}_{2} \mathrm{O}$ and $\mathrm{SiO}_{2}$ (Fig. 6) are also consistent with no K-feldspar removal. In addition, the lack of $\mathbf{K}$-feldspar and biotite fractionations are also confirmed by the absence of a negative Ba anomaly in the primitive mantlenormalized rare earth element patterns (Fig. 8B).

\subsubsection{Biotite}

Fractionation of biotite and $\mathbf{K}$-feldspar should buffer or reduce $\mathbf{B a}$ in the residual liquid (Blundy and Wood, 2003). In Figs. 6 and 7, $\mathrm{K}_{2} \mathrm{O}$

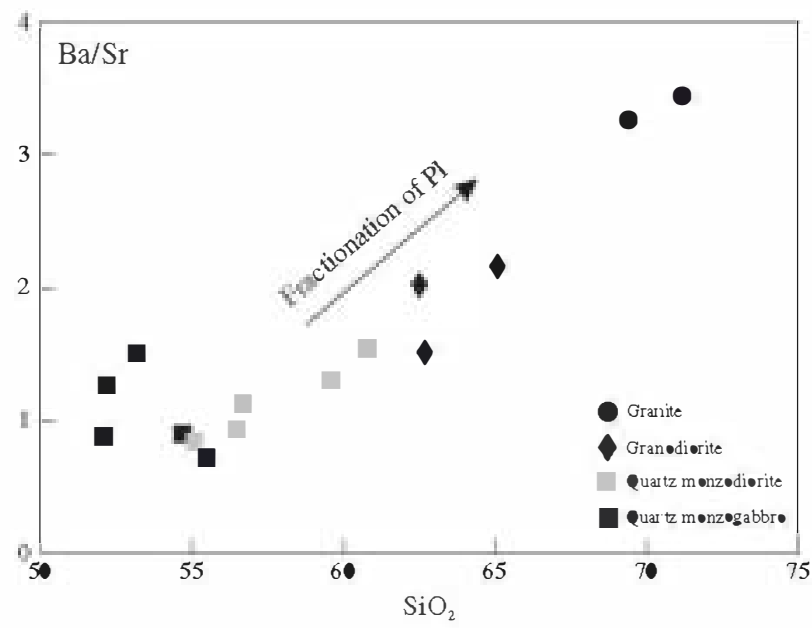

Fig. 14. Increasing $\mathrm{Ba} / \mathrm{Sr}$ vs. $\mathrm{SiO}_{2}$ indicates fractionation of plagioclase rather than K-feldspar in the Khalkhab-Neshveh rocks (Rollinson, 1993). Abbreviations are after Kretz (1983). 
A

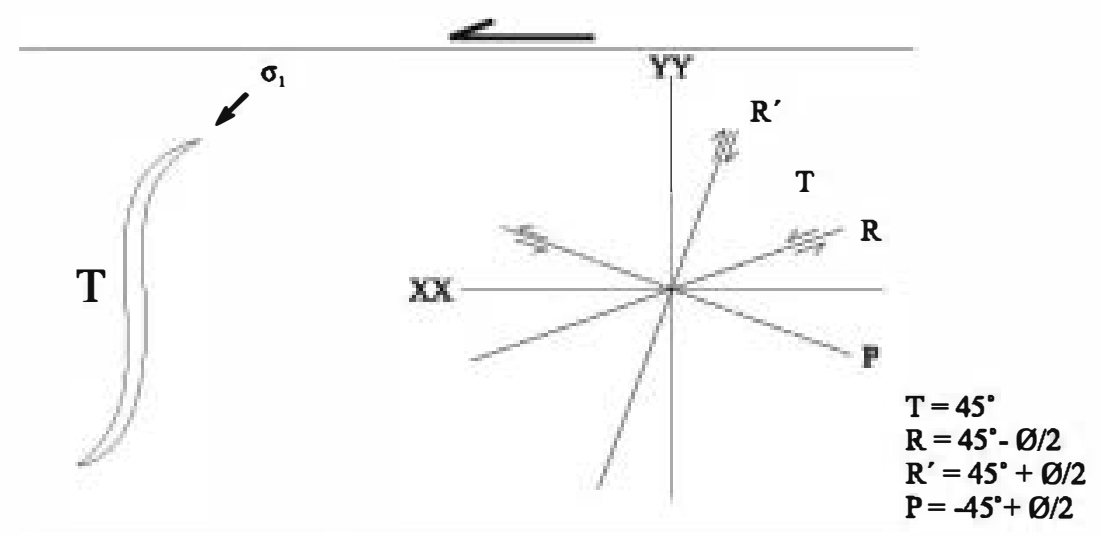

B

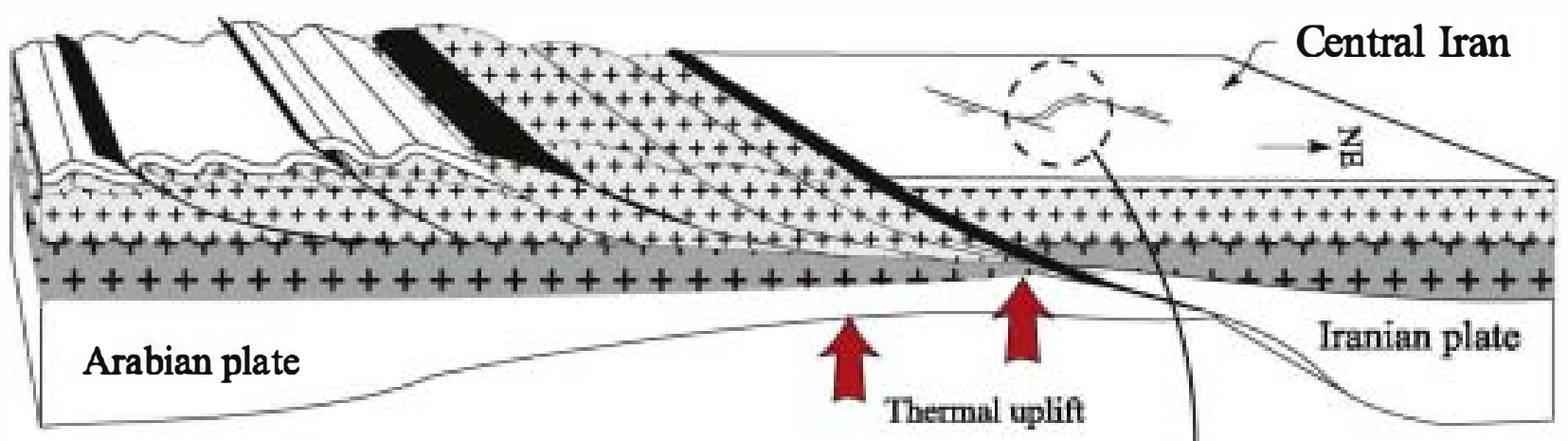

\section{Slab break-off}

C

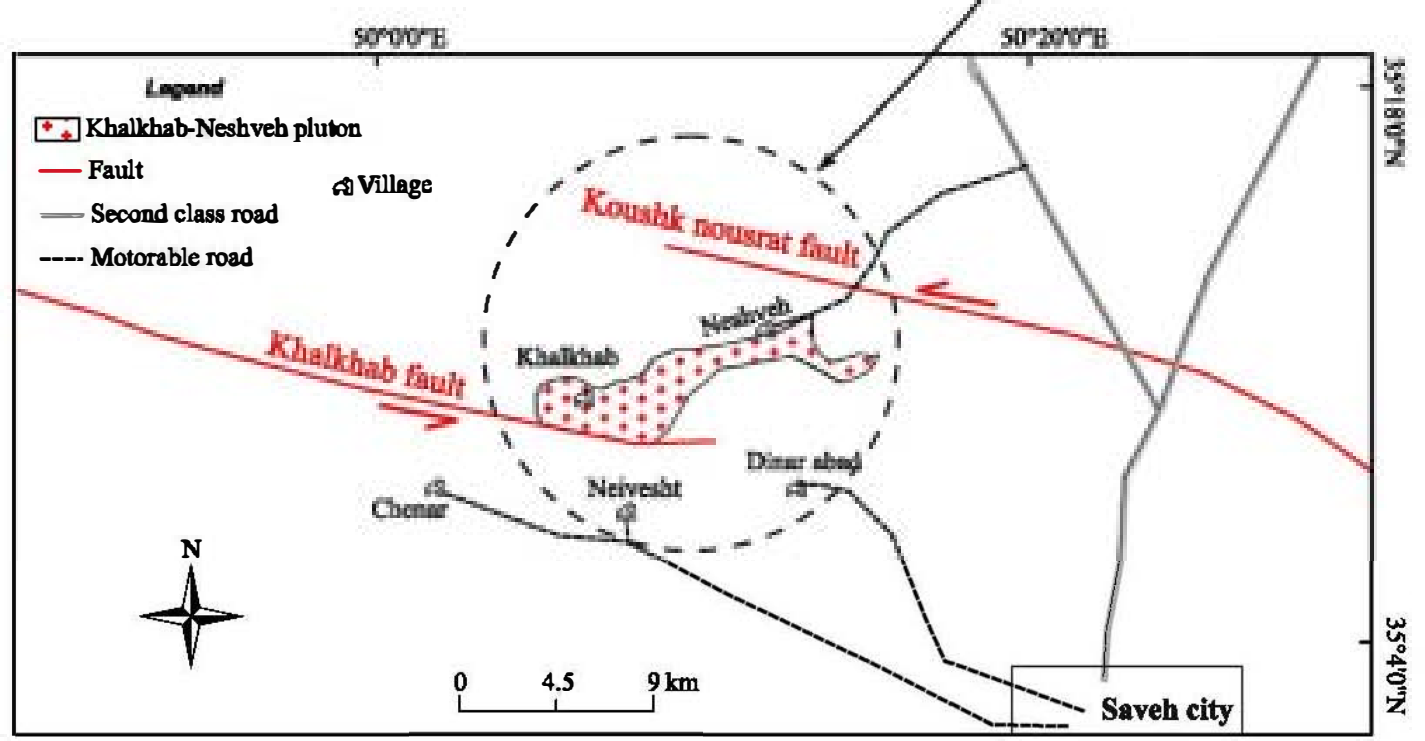

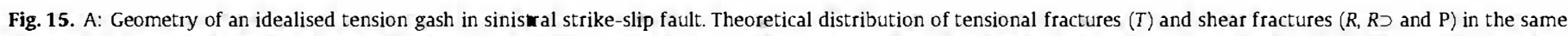

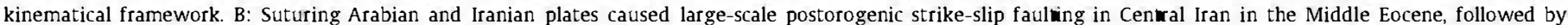

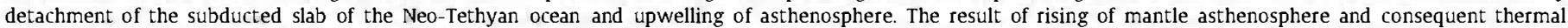

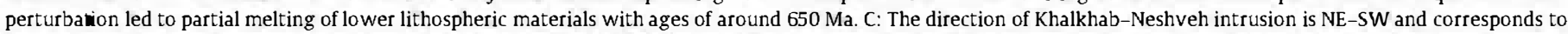

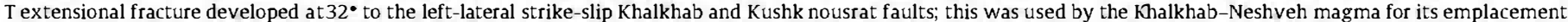
after middle Eocene. 
and Ba contents increase from 1.21 and 247, respectively, in quartz monzogabbro to $5.14 \%$ wt and 808 ppm in granite (see also Table 2), indicating that biotite and $\mathbf{K}$-feldspar crystallized late or sank very slowly in co-existing melt during magmatic differentiation. As presented in Table 1, biotite content decreases in the granitic samples, thus the increase in $\mathbf{B a}$ in these samples is mostly related to latecrystallized $\mathbf{K}$-feldspar in the magma.

\subsubsection{Apatite}

The regular decrease in $\mathrm{P}_{2} \mathrm{O}_{5}$ content from the quartz monzogabbroic to granitic rocks (Fig. 6) is attributed to fractionation of apatite (Broska et al., 2004).

\subsubsection{Zircon}

The concentration of $\mathrm{Zr}$ in mafic magmas increases up to the point at which they become saturated and zircon begins to crystallize (Hoskin and Schaltegger, 2003). Since Zr increases with silica in the Khalkhab-Neshveh rocks, zircon was not precipitated during magma evolution and this is consistent with its absence from the quartz monzogabbro, quartz monzodiorite and granodiorite and its paucity in the granitic rocks. It might also have crystallized from the interstitial melt but this would have had little effect on the $\mathrm{Zr}$ evolution trend.

\subsubsection{Titanite}

Ti-bearing minerals such as ilmenite and titanite might be other fractionated phases in the Khalkhab-Neshveh magmas, as suggested by the decrease of $\mathrm{TiO}_{2}$ with increasing $\mathrm{SiO}_{2}$ (Fig. 6). Moreover, as hornblende and biotite fractionated from the magma forming rocks with $\mathrm{SiO}_{2}>62$, a combination of ilmenite, titanite, hornblende and biotite fractionations can be considered responsible for the decreasing $\mathrm{TiO}_{2}$ in granodioritic and granitic melts. There is a larger negative $\mathrm{Ti}$ anomaly in the granitic rocks and decreasing $\mathrm{Dy} / \mathrm{Yb}$ ratio vs. $\mathrm{SiO}_{2}$ in the representative samples (Fig. 8B and Fig. 13A).

\subsection{A tectonomagmatic model for the pluton}

Based on the emplacement mechanisms, intrusive bodies have been classified into two main groups: forceful intrusions (e.g., diapirs and dykes; Cruden, 1988; Clemens and Mawer, 1992), and permitted intrusions assisted by brittle or ductile deformations (Castro, 1985; Guineberteau et al., 1987; Hutton et al., 1990). This classification mainly depends on the crustal level of pluton emplacement and the regional tectonic setting.

Evidence for the source, ascent and consequent emplacement of a magma, represented now by a pluton, is difficult to observe in the field. Such processes may be inferred from the petrological and rheological characteristics of a magma and its country rocks, the geometry of pluton and the main direction of stress in a region. In the following we try to provide a tectonomagmatic model for the Khalkhab-Neshveh pluton by combining the information of regional geology, geophysics, age and the inferred source of representative samples.

Experimental and field studies have resulted in a widely accepted model of shear fracture orientation during non-coaxial deformation, illustrated in Fig. 15A (Coelho et al., 2006). The most conspicuous element of this idealised geometry for plutonic emplacement is the purely tensional T fractures (at $45^{\circ}$ in strikeslip faulting), comprising synthetic Riedel fractures $(R)$ and conjugate antithetical Riedel fractures $\left(R^{\prime}\right)$, oriented at $45^{\circ} \pm \varphi / 2$, where $\varphi$ is the internal angle of friction of the rock.

The suturing of Arabia and Iran increased the thickness of the Urumieh-Dokhtar crust to about $52 \mathrm{~km}$ (Molinaro et al., 2005) and caused large scale postorogenic strike-slip faulting in this region in the Early to Middle Eocene (Ghasemi and Talbot, 2006).
Following that, the slab of subducted Neo-Tethyan oceanic lithosphere detached from Arabia and sank (Bird, 1978) in the Middle Eocene. This rupture began in the studied area and adjacent regions in the Middle Eocene and opened southwards like a zip-fastener. The asthenosphere welled up into the intra-plate gap opened by slab break-off behind the suture and caused a thermal anomaly below the Urumieh-Dokhtar region (Fig. 15B; Molinaro et al., 2005).

In the studied area there are two parallel left-lateral strike-slip faults, the Khalkhab and Koushk nousrat. As shown in Fig. 15C, the Khalkhab-Neshveh pluton is limited by these faults in the north and south and defines an angle of $32^{\circ}$ to the fault trends.

Considering the geochemical and isotope data, it is suggested that the $38 \mathrm{Ma}$ old Khalkhab-Neshveh pluton is a calc-alkaline and volcanic-arc intrusion (Figs. 5 and 8 ) which may have been generated by dehydration melting of $650 \mathrm{Ma}$ lithospheric mantle or mafic lower crust during a period of subsidiary subduction of Arabian plate beneath the Iranian block to the north and after initial suturing in the middle Eocene. Structural and stratigraphic studies, geophysical information, and the geometry of the pluton suggest that suturing between Arabian and Iranian plates caused left-lateral strike-slip faults in the Iranian plate in the middle Eocene, followed by slab break and rising mantle asthenosphere to an average depth of $100 \mathrm{~km}$ beneath Urumieh-Dokhtar region (Molinaro et al., 2005). The strongest evidence for this scenario is the positive geoid anomaly, which reflects a topography that is partly compensated by deeper density variations in the lower lithosphere. Recent global tomographic models (Bijwaard and Spakman, 2000; Molinaro et al., 2005) show a pronounced negative velocity anomaly beneath central Iran which also confirms the upwelling of mantle asthenosphere.

The rising of mantle asthenosphere and the consequent thermal perturbation led to partial melting of the lower continental lithosphere. The magma thus generated flowed upwards through weaknesses in the surrounding solid rocks of the crust.

As shown in the map area (Fig. 15C), the direction of intrusion is NE-SW, thus the ascent conduits may correspond to T extensional fracture developed at an angle of $32^{\circ}$ to the left-lateral strike-slip Khalkhab and Kushk nousrat faults. The $\mathrm{T}$ extensional fracture was exploited by the magma for its emplacement (Fig. 15B and C).

\section{Conclusions}

The wide compositional and mineralogical range of the Khalkhab-Neshveh pluton, from quartz monzogabbro through to granite, is typical of a calc-alkaline arc intrusion. The field characteristics, together with isotope and geochemical analysis, show that all rock types were essentially co-magmatic and that the principal mode of differentiation was crystal fractionation of mineral phases commonly present as phenocrysts in the mineral assemblage at different stages, clinopyroxene in the quartz monzogabbro, clinopyroxene, hormblende and plagioclase in the quartz monzodiorite, and hornblende, plagioclase \pm biotite thereafter. $\mathrm{K}$ feldspar, biotite and quartz are progressively concentrated in the granodiorite and granite, but did not separate from them in large amounts until the final stage of $\mathrm{SiO}_{2}$ enrichment (to a little over $70 \%)$.

The initial magma from which the pluton developed was probably similar to the most mafic rock type exposed, the quartz monzogabbro, with about $52 \% \mathrm{SiO}_{2}$. This might have been derived from metasomatized mantle or lower continental crust with low $\mathrm{Rb} / \mathrm{Sr}$ and a maximum age of separation from the mantle of around $650 \mathrm{Ma}$. No upper crustal rocks were involved in the generation of the magma or its differentiation in the arc. Furthermore, collision of Arabian and Iranian plates caused left-lateral strike-slip 
Khalkhab and Kushk nousrat faults on Iranian plates and created a sigmoid space for the emplacement of pluton after middle Eocene.

\section{Acknowledgments}

Authors would like to thank University of Tehran for supporting this project under grants provided by research council. We acknowledge $A$. Castro and $C$. Miller for their constructive comments leading to important improvements in the manuscript. We are also grateful to $\mathrm{C}$. Casquet for his helpful comments and suggestions.

\section{References}

Agard, P., Jolivet, L., Vrielynck, B., Burov, E., Monie, P., 2007. Plate acceleration: the obduction trigger? Earth and Planetary Science Letters 258, 428-441.

Aghanabati, A., 1998. Major sedimentary and structural units of Iran (map). Geosciences 7, Geological Survey of Iran.

Aghanabati, A., 1991. Magmatic rocks of Iran, 1: 2,500,000 survey sheet. Geological Survey of Iran.

Aghazadeh, M., Castro, A., Omran, N.R., Emmani, M.H., Moinvaziri, H., Badrzadeh, Z., 2010. The gabbro (shoshonitic)-monzonite-granodiorite association of Khankandi pluton. Alborz Mountains, NW Iran. Journal of Asian Earth Sciences 38, 199-219.

Ahmadian, J., Haschke, M., McDonald, I., Regelous, M., Ghorbani, M.Reza, Emami, M.H., Murata, M., 2009. High magmatic flux during Alpine-Himalayan collision: Constraints from the Kal-e-Kafi complex, central Iran. Geological Society of America Bulletin 121, 857-868.

Arndt, N.T. Coldstein, S.L. 1989. An open boundary between lower continental crust and mantle: its role in crust formalion and crustal recycling. Tectonophysics 161, 201-212.

Bea, F., Fershtater, G.B., Montero, P., Smimov, V.N., Molina, J.F., 2005. Deformationdriven differentiation of granitic magma: The Swepninsk pluton of the Uralides, Russia. Lithos 81, 209-233.

Berberian, F., Muir, I.D., Pankhurst, R.J., Berberian, M., 1982. Late cretaceous and early miocene andean-type plutonic activity in Northern Makran and Central Iran. Journal of the Geological Society 139, 605-614.

Bergantz, G.W., 1989. Underplating and partial melung: implications for melt generation and extraction. Science 245, 1093-1095.

Bijwaard, H., Spakman, W., 2000. Non-linear global P-wave tomography by iterated linearized inversion. Geophysical Journal International 141, 71-82.

Bird, P., 1978. Finite element modeling of lithosphere deformation: the Zagros collision orogeny. Tectonophysics $50,307-336$.

Blevin, P.L., Chappell, B.W'., 1992. The role of magma sources, oxidation states and fractionation in determining the granite metallogeny of eastern Australia Transactions of the Royal Society of Edinburgh: Earth Sciences 83, 305-316.

Blundy. J., Wood, B., 2003. Partitioning of race elements between crystals and melts. Earth and Planetary Science Letters 210, 383-397.

Boynton, W.V., 1984. Cosmochemistry of the rare earth elements: meteorite studies. In: Henderson, P. (Ed.) Rare Earth Element Geochemistry. Elsevier, pp. 63-114.

Broska, I., Williams, C.T., Uher, P., Konečný, P., Leichmann, J., 2004. The geochemistry of phosphorus in different granite suites of the Western Carpathians, Slovakia: the role of apatite and P-bearing feldspar. Chemical Geology 205, 1-15.

Castro, A., 1985. The central extremadura batholith: geotectonic implications (European Hercynian belt). An outline. Tectonophysics 120, 57-68

Chappell, B.W., 1996. Magma mixing and the production of compositional variation within granite suites: evidence from the granites of southeastern Australia. Journal of Petrology 37, 449-470.

Chappell, B.W., White, A.J.R., Wyborn, D., 1987. The importance of residual source material (restite) in granite petrogenesis. Journal of Petrology 28, 1111-1138.

Claeson, D.T., Meurer, W.P., 2004. Fractional crystallization of hydrous basaltic "arctype" magmas and the formation of amphibole-bearing gabbroic cumulates. Contributions to Mineralogy and Petrology 147, 288-304.

Clemens, J.D., Mawer, C.K, 1992. Granitic magma transport by fracture propagation. Tectonophysics 204, 339-360.

Cocherie, A., 1986. Systematic use of race element distribution patterns in log-log diagrams for plutonic suites. Geochimica et Cosmochimica Acta 50, 2517-2522.

Coelho, S. Passchier, C., Marques, F., 2006. Riedel-shear control on the developmen of pennant veins: field example and analogue modelling. Journal of Structural Geology 28, 1658-1669.

Cruden, A.R., 1988. Deformation around a rising diapir modeled by creeping flow past a sphere. Tectonics 7, 1091-1101.

Davarpanah, A, 2009. Magmatic evolution of eocene volcanic rocks of the BijgerdKuh-e Kharchin area, Uromieh-Dokhtar Zone, Iran. Master of Science Thesis. Georgia State University.

Davidson, J., Turner, S., Handley, H., Macpherson, C., Dosseto, A., 2007. Amphibole "sponge" in arc crust? Geology 35, 787-790.

DePaolo, D.J., 1981. Trace element and isotopic effects of combined wall rock assimilation and fractional crystallization. Earth and Planetary Science Letters $53,189-202$
DePaolo, D.J., Linn, A.M., Schubert, G., 1991. The continental crustal age distribution; methods of determining mantle separation ages from Sm-Nd isotopic data and application to the Southwestern United States. Journal of Geophysical Research 96, 2071-2088.

Dercourt, J., Zonenshain, L.P., Ricou, L.E., Kazmin, V.G., Le Pichon, X., Knipper, A.L., Grandjacquet, C., Sbortshikov, I.M., Geyssant, J., Lepvrier, C., Pechersky, D.H., Boulin, J., Sibuet, J.C., Savostin, L.A., Sorokhtin, O., Westphal, M., Bazhenov, M.L., Lauer, J.P., Biju-Duval, B., 1986. Geological evolution of the Tethys belt from the Atlantic to the Pamirs since the Lias. Tectonophysics $123,241-315$.

Dias, G., Leterrier, J., 1994. The genesis of felsic-mafic plutonic associations: a Sr and Nd isotopic study of the Hercynian Braga Granitoid Massif (Northem Portugal) Lithos 32, 207-223.

Eichelberger, J.C., 1980. Vesiculation of mafic magma during replenishment of silicic magma reservoirs. Nature $288,446-450$.

Furlong, K.P., Fountain, D.M., 1986. Continental crustal underplating: thermal considerations and seismic-petrologic consequences. Journal of Geophysical Research 91, 8285-8294.

Galán, G., Pin, C., Duthou, J.L., 1996. Sr-Nd isotopic record of multi-stage interactions between mantle-derived magmas and crustal components in a collision context-the ultramafic-granitoid association from Vivero (Hercynian belt, NW Spain). Chemical Geology 131, 67-91.

Ghalamghash, J., 1998. Geological map of Saveh 1:100000 survey sheet. Geological survey of Iran.

Ghasemi, A., Talbot, C.J., 2006. A new tectonic scenario for the Sanandaj-Sir jan Zone (Iran). Journal of Asian Earth Sciences 26, 683-693.

Ghasemi, H., Ramazani, A., Khanalizadeh, A., 2008. Petrology, geochemistry and tectonomagmatic setting of the Silijerd intrusion, Northwest Saveh. Scientific Quarterly Journal of Geosciences $17,68-85$

Green, D.H., 1980. Island arc and continent building magmatism a review of petrogenic models based on experimental petrology and geochemistry. Tectonophysics $63,367-385$.

Guineberteau, B., Bouchez, J.L., Vigneresse, J.L., 1987. The Mortagne granite pluton (France) emplaced by pull-apart along a shear zone: swuctural and gravimewric arguments and regional implication. Ceological Society of America Bullewin 99, $763-770$.

Hassanzadeh, J., 1993. Me llogenic and Tectonomagmatic Events in the SE Sector of the Cenozoic Acrive Continental Margin of Central Iran. University of California, Los Angeles, p. 204.

Hildreth, W., 1981. Gradients in silicic magma chambers: implications for lithospheric magmatism. Journal of Geophysical Research 86, 10153-10192.

Hoskin, P.W.O., Schaltegger, U., 2003. The composition of zircon and igneous and metamorphic petrogenesis. Reviews in Mineralogy and Geochemistry 53, 2762.

Hutton, D.H.W., Dempster, T.J., Brown, P.E., Decker, S.D., 1990. A new mechanism of granite emplacement: intrusion in active extensional shear zones. Nature 343 , $452-455$.

Klimm, K, Holtz, F., King, P.l., 2008. Fractionation vs. magma mixing in the wangrah suite A-type granites, Lachlan Fold Belt, Australia: experimental constraints. Lithos 102, 415-434.

Kuritani, T., Kitagawa, H., Nakamura, E., 2005. Assimilation and fractional crystallization controlled by transport process of crustal melt: implications from an alkali basalt dacite suite from Rishiri Volcano, Japan. Journal of Pewology 46, 1421-1442.

Kretz, R., 1983. Symbols for rock-forming minerals. American Mineralogist68, 277279.

Iassen, B., Bridgwater, D., Bernstein, S., Rosing, M., 2004. Assimilation and highpressure fractional crystallization (AFC) recorded by Paleo-proterozoic mafic dykes, Southeast Greenland. Lithos 72, 1-18.

McQuarrie, N., Stock, J.M., Verdel, C., Wernicke, B.P., 2003. Cenozoic evolution of Neotethys and implications for the causes of plate motions. Geophysical Research Letters 30, 2036. doi: 10.1029/2003CL017992.

Meyer, B., Mouthereau, F., Lacombe, O., Agard, P., 2005. Evidence for Quaternary activity along the Deshir Fault: implication. Geophysical Journal International $163,1-10$

Middlemost, E.A.K., 1985. Magmas and Magmatic Rocks. An Introduction to Igneous Pewology. Longman Group Ltd, London. New York, p. 266.

Molinaro, M., Guezou, J.C., Leturmy, P., Eshraghi, S.A., Frizon de Lamotte, D., 2004. The origin of changes in swuctural style across the Bandar Abbas syntaxis SE Zagros (Iran). Marine and Petroleum Geology 21, 735-752.

Molinaro, M., Zeyen, H., Laurencin, X., 2005. Lithospheric structure beneath the southeastern Zagros Mountains, Iran: recent slab break-off? Terra Nova 17, 1-6.

Pecerillo, A., Taylor, S.R., 1976. Geochemistry of eocene calc-alkaline volcanic rocks from the Kastamonou area, Northern Turkey. Contriburions Mineralogy and Pewology 58, 63-81.

Popov, V.S., Tevelev, A.A., Bogatov, V.I., 1999. The Stepninsk pluton on the south Urals: relationships of plutonic rocks coming from mantle and crustal sources. Izv. VUZov Geologiya Razved 5, 52-68.

Rickwood, P.C., 1989. Boundary lines within petrologic diagrams which use oxides of major and minor elements. Lithos 22, 247-263.

Ricou, L.E., Braud, J., Brunn, J.H., 1977. Le Zagros. Socie'te Geologique de France. Me'moires 8, 33-52.

Roberts, M.P., Clemens, J.D., 1995. Feasibility of AFC models for the perrogenesis of calc-alkaline magma series. Contributions to Mineralogy and Petrology 121 , 139-147.

Rollinson, H.R., 1993. Using Geochemical Data: Evaluation, Presentation, Interpretation. Harlow: Longman, p. 352. 
Schmidt, A., Weyer, S., Brey, G.P., 2006. BSE reservoirs: insights from Nb/Ta of rutilebearing eclogites. Goldschmidt Conference Abstracts. Page A562.

Sha, L.K., Chappell, B.W., 1999. Apatite chemical composition, determined by elecron microprobe and laser-ablation inductively coupled plasma mass spectrome y, as a probe intogranite petrogenesis. Geochimica et CosmochimicaActa 63, 3861-3881.

Shahbazi, H., Siebel, W., Pourmoafee, M., Ghorbani, M., Sepahi, A.A., Shang, C.K., Vousoughi Abedini, M., 2010. Geochemistry and U-Pb zircon geochronology of the Alvand plutonic complex in Sanandaj-Sir jan Zone (Iran): new evidence for Jurassic magmatism. Journal of Asian Earth Sciences 39, 668-683.

Spera, F.J., Bohrson, W.A., 2001. Energy-constrained open system magmatic processes I: general model and energy-constrained assimilation and fractional crystallization (EC-AFC) formulation. Journal of Petrology 42, 999-1018.

Steiger, R.H., Jäger, E., 1977. Subcommission on geochronology: convention on the use of decay constants in geo- and cosmo-chronology. Earth and Planetary Science Letters $36,359-362$.

Sun, S.S., McDonough, W.F., 1989. Chemical and isotopic systematics of oceanic basalts: implications for mantle composition and processes. In: Saunders, A.D., Norry, M.J., (Eds.), Magmatism in the Ocean Basins, Geological Society London, vol. 42. pp. $313-345$.

Talebian, M., Jackson, J., 2004. A reappraisal of earthquake local mechanisms and active shortening in the Zagros mountain of Iran. Geophysical Journal International 156, 506-526.

Thompson, A.B., Matile, L., Ulmer, P., 2002. Some thermal constraints on crustal assimilation during fractionation of hydrous, mantlederived magmas with examples from central Alpine batholiths. Journal of Perrology 43, 403-422.

Tindle, A.G., Pearce, J.A., 1981. Petrogeneric modelling of in situ fractional crystallization in the zoned Loch Doon pluton, Scotland. Contriburions to Mineralogy and Petrology 78, 196-207.
Torabi, G., 2009. Subduction-related Eocene Shoshonites from the Cenozoic Urumieh-Dokhrat Magmatic Arc (Qaleh-Khargooshi Area, Western Yazd province, Iran). Turkish Journal of Earth Sciences 18, 1-34.

Verma, S.P., 2001. Geochemical and Sr-Nd-Pb isotopic evidence for a combined assimilation and fractional crystallisation process for volcanic rocks from the Huichapan caldera, Hidalgo, Mexico. Lithos 56, 141-164.

Vernant, Ph., Nilforoushan, F., Hatzfeld, D., Abbassi, M.R., Vigny, C., Masson, F, Nankali, H., Martinod, J., Ashtiani, A., Bayer, R., Tavakoli, F., Chery, J., 2004 Present-day crustal deformation and plate kinemarics in the Middle East conswained by GPS measurements in Iran and northern Oman. Geophysical Journal International 157, 381-398.

Walker, A.J., Carr, J.M., 1986. Compositional variations caused by phenocryst sorting at Cerro Negro volcano, Nicaragua. Geological Society of America 97, 11561162.

Wei, L., Congqiang, L., Masuda, A., 1997. Complex trace-element effects of mixingfractional crystallization composite processes: applications to the Alaer granite pluton, Altay Mountains, Xinjiang, northwestern China. Chemical Geology 135, $103-124$

White, A.J.R., Chappell, B.W., 1983. Granitoid types and their distribution in the Lachlan Fold Belt, southeastern Australia. Geological Society of America Memoir $159,21-34$

Wilson, M., 2007. Igneous Perrogenesis. Chapman \& Hall, London, p. 411.

Winter, J.D., 2001. An Introduction to Igneous and Metamorphic Perology. Prentice Hall, New Jersey.

Wyborn, D., Chappell, B.W., James, M., 2001. Examples of convective fractionation in high temperature granites from the Lachlan Fold Belt. Australian Journal of Earth Sciences 48, 531-541. 